\title{
IESKATS 1587. UN 1615. GADA PERIKOPJU KRĀJUMOS: IZMAIN̦AS
}

\author{
Ernesta KAZAKĖNAITE் \\ Vilı,nas Universitāte
}

\section{Ievads}

Pirmoreiz perikopju krājums latviešu valodā izdots 1587. g. Kēnigsbergā. ${ }^{1}$ Kopā ar Mārtiņa Lutera Mazo katķismu (1586), psalmiem un garīgām dziesmām (1587) tas veido tā saucamo Kurzemes rokasgrāmatu (SLV: 3, 4, 5). Kā visas grāmatas sastādītāji minēti četri mācītāji - Kristians Miks, Balcers Lembroks, Johanness Vegmanis un Gothards Reimerss -, tomēr tiešie perikopju krājuma tulkotāji nav zināmi². Par galveno redaktoru Jānis Straubergs (1936:473-476) uzskatīịis Miku, lai gan tas grāmatā nav minēts. Šî tulkojuma avoti, pateicoties Pētera Vanaga pētījumiem (1994; 2000), ir pietiekami skaidri - sākotnēji tulkots no kāda lejasvācu izdevuma starp 1532. un 1541. g., tomēr galvenais avots bijusi kāda Lutera Bībele lejasvācu valodā pēc 1545. g. galīgās redakcijas (Vanags 2000: 387; arī Augstkalns 1930: 98). Tātad perikopju krājums netapa tukšā vietā, bet ir arī kādu agrāku tulkojumu kontaminējums.

1587. gada perikopju izdevums (tālāk - EE1) bija paredzēts Kurzemes baznīcām, tomēr jau pēc 28 gadiem - 1615. g. — grāmata atkārtoti izdota Rīgā (tālāk - EE2). ${ }^{3}$ Domājams, ka tā Mollīna tipogrāfijā izdota pēc rātes uzdevuma, lai panāktu luterāņu dievvārdu unifikāciju, jo pirmais izdevums jau bija

1 Nosaukums-Euangelia vnd Epifteln / aus dem deud=fchen in vndeudfche Sprache gebracht / fo durchs gantze Jar / auff alle Sontage vnd fürnem=ften Fefte / in den Kirchen des Fürften=thumbs Churlandt vnd Semigallien in Lieffland vor die vndeudfchen gelefen werden. Mit der Hiftorien des Lei=dens / vnd Aufferftehung vn=fers HErrn Jefu Chrifti / aus den vier Euange=liften, Gedruckt zu Königsperg in Preuffen / bey Georgen Ofterbergern. M, D. LXXXVII. [internetā: http://www. korpuss.lv/senie/static/EvEp1587.html]. Pašlaik ir zināmi divi perikopju krājuma eksemplāri, abi, gatavojot rakstu, apskatīit de visu. Viens atrodas Latvijas Nacionālajā bibliotēkā Rīgā (šifrs L2S 128), otrs, defektīvs, - Tartu Universitātes bibliotēkā Igaunijā (šifrs R III.V.1.; sk. SLV: 4).

2 Vācu Christian Mick, Baltzer Lembrock, Johannes Wegman, Gothard Reymers. Zināms, ka viṇi izmantojuši arī Johannesa Rīvija atstātos manuskriptus (Vanags 2000: 38).

3 Nosaukums - Euangelia vnd Epifteln / aus dem Teut=fchen in die Lieffländifche Pawrfprache gebracht / fo durchs gantze Jahr auff alle Sonta=ge vnd fürnemften Feften in der Kirchen Gottes zu Riga / vnd andern örtern Liefflandes mehr / vor das gemeine Haußgefinde vnd Pawren gelefen / vnd erklehrt werden Mit der Hiftorien des Leidens vnd Auff=erftchung vnfers Herrn Jefu Chrifti aus den vier Euangeliften. Cum Grat.\& Priv. Ser. Reg. Majeft. Polonis. Gedruckt in der Konigi. Seeftadt Riga im Liefflandt / bey Nicolaus Mollin / 1615. [internetā: http://senie.korpuss.lv/ static/EvEp1615.html]. Zināmi četri eksemplāri, kas iedalāmi divās grupās atkarībā no tā, vai tiem ir Polijas karạ̦a aț̣auja un privilēǵijas: 1. grupa (bez ievietotas aț̣aujas) - N̦ujorkā, Tartu un Virtembergā, 2. grupa (ar ievietotu aț̣auju, sk. citētajā nosaukumā) - tikai Latvijas Nacionālajā bibliotēkā Rīgā (SLV: 6). 
izgāiis no apgrozības (Apīnis 1977:46; Zanders 1988: 98). Otrais triju grāmatu izdevums tiek saukts par Vidzemes rokasgrāmatas pirmo izdevumu (sal. SLV: $6,7,8)^{4}$. Par šīs grāmatas tapšanu, iespējams, ir zināms pat mazāk nekā par pirmo - lai gan ir minējumi ${ }^{5}$, izdevēja Mollīna ievadvārdos iespējamo redaktoru uzvārdi nav atrodami. No trim rokasgrāmatas dalā̄m īpaša uzmanība pievērsta tikai dziesmu grāmatai (Straubergs 1934; Apīnis 1991; Vanags 2000), jo tajā publicēts trīsreiz vairāk dziesmu nekā 1587. g. Taču šì izdevuma perikopiu krājums tikpat kā nav pētìts, un līdz ar to tas kḷuva par šā raksta mērḳi.

Pastāv uzskats, ka 1615. g. perikopju krājums iespiests praktiski bez izmaiņām (sk. Augstkalns 1933:53; Apīnis 1991:23; Vanags 2000: 367). Lielākoties tā arī ir - krājuma struktūra netika mainīta, tomēr, salīdzinot abu grāmatu perikopju tekstu, atrodamas dažādas izmaiņas rakstībā, morfolog̣ijā, vārddarināšanā, leksikā, sintaksē un teikuma uzbūvē, bet jāpiebilst, ka to daudzums ievērojami atšķiras (sk. 1. diagrammu). Zinot, ka 17. gs. sākums vēl ir grafizācijas izvēles periods (Vanags 2013: 178), nepārsteidz, ka tieši rakstībā ir visvairāk izmaiņu, t. i., piln̄̄gi visās EE perikopēs. Te daudzviet vārda sākumā mazie burti nomainīti uz lielajiem (bet $\rightarrow$ Bet, Jefum $\rightarrow$ JEfum), retumis arī otrādi (Layx $\rightarrow$ layx), vietām pielikts vai retāk nodzēsts $h$ aiz $t$ vai $k$ (to $\rightarrow$ tho, thas $\rightarrow$ tas), itin bieži $y$ nomainīts uz $i$ (Szyrdes $\rightarrow$ Szirdes) vai - piecas reizes retāk - otrādi $i \rightarrow y$ $(\text { tudelin } \rightarrow \text { tudelyn })^{6}$, nekonsekventi atmests viens no diviem kopā rakstītiem ee gan vārda saknē (dreebims $\rightarrow$ drebims), gan izskaņā (redtczeeth $\rightarrow$ redtczeth), bet retāk arī otrādi - pielikts klāt ( petczibe $\rightarrow$ jpeetczibe) utt. ${ }^{7}$ Tomēr dažviet EE2 ne tikai piel̦autas jaunas korektūras kḷūdas (mettet et $v \beta$ tho (1Pēt 5:7)), bet arī atstātas vecās (dar=dyth $\rightarrow$ dardyth (Jñ 3:2) 'darīt'; liake (Mt 24:21) 'laikā'). Šāda drukātam tekstam raksturīgo korektūras kḷūù pārṇemšana liek domāt, ka jaunā EE redakcija gatavota no manuskripta, kas radies no drukāta EE1 teksta, nevis no kāda vecāka palikuša rokraksta, kā tiek uzskatīts par 1615. g. kopā izdoto dziesmu grāmatu (Apīnis 1977: 46).

4 Lai gan grāmatas iesietas kopā, no grāmatniecības viedokḷa tās ir trīs atseviškłas grāmatas, jo katrai ir sava titullapa, numerācija, māksliniecisks noformējums, un tās arī iespiestas uz atškşirīga papīra (Apīnis 1977: 48-49; Zanders 1988: 91).

5 Straubergs (1936b: 18) ir izteicis domu, ka galvenais dziesmu grāmatas redaktors esot bijis Rīgas latviešu draudzes mācītājs Andreass Šìrings vai tās diakons Gregorijs Bauers. Šo apgalvojumu apšaubīinis Vanags (2000: 44), kas, ņemot vērā grāmatas tekstu lielo dažādību, kā vienu no iespējām min, ka redaktora vispār nav bijis.

6 Te vērojama gandrīz konsekventa $i$ nomaiņa pret $y$, kad tas apzīmē $j$, piem., ieb $\rightarrow$ yeb, ieme $\rightarrow$ yeme.

7 Patiesībā te var saskatīt arī kādu tendenci: biežāk ar diviem ee apzīmētas gaidāmas garas zilbes, piem., Grekis $\rightarrow$ Greekes (Gal 3:28), Swetyet $\rightarrow$ Sweetyet (Rm 12:14), dhewetcz $\rightarrow$ dheweetcz (Lk 2:21). 


\section{Izmaiņu tipu sadalījums perikopēs pēc to kārtas EE}

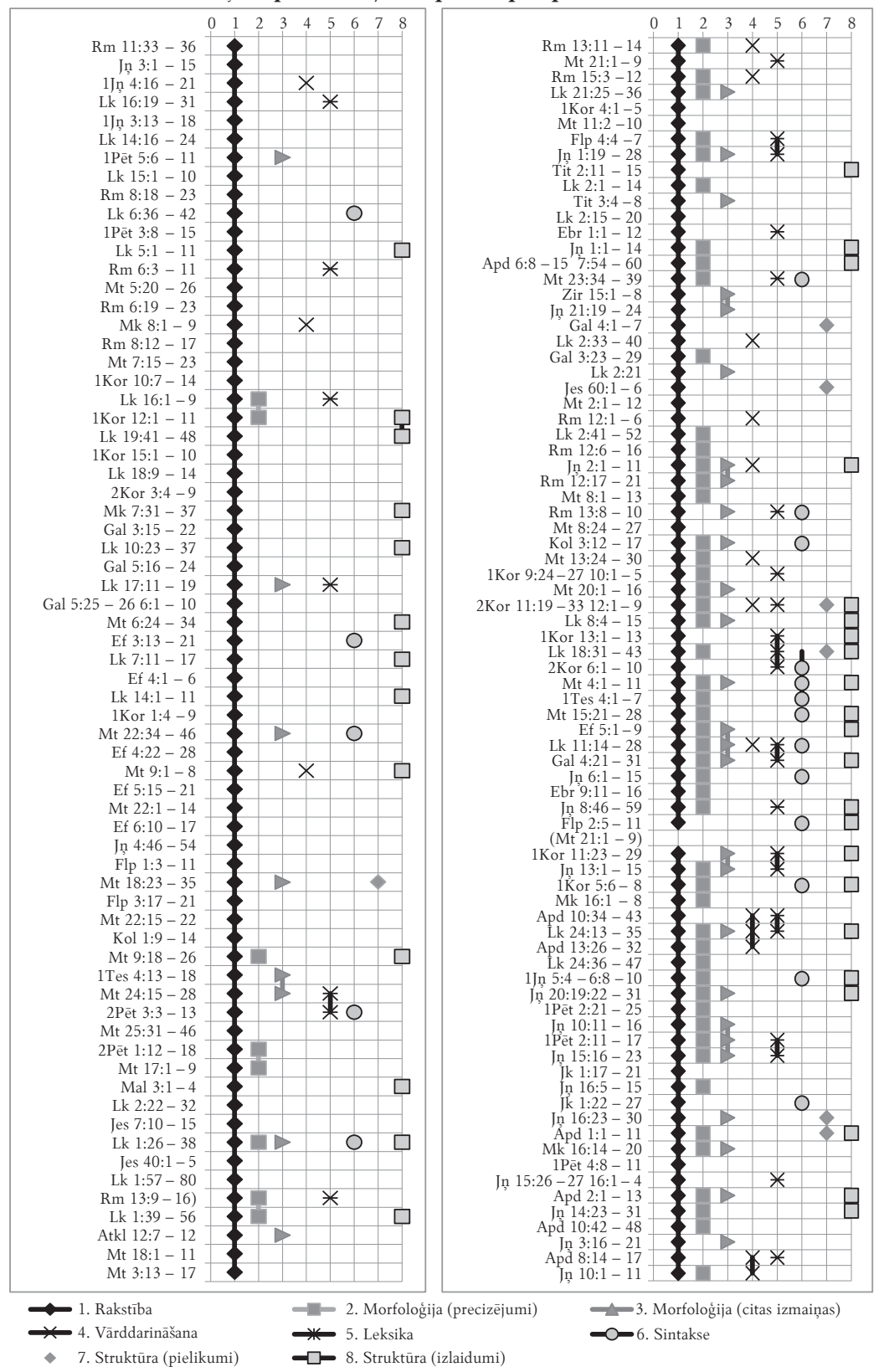


EE savdabīgās ortogrāfijas dēḷ nereti grūti pateikt, vai konkrēts gadījums ir apzināta maiņa vai nav, tāpēc jāatzīst, ka pētījums ortogrāfijas ziņā ir nosacīts. Līdz ar to šajā rakstā tiks aplūkota daļa no 1615. g. perikopēs identificējamām izmaiņām - neņemot vērā rakstības, resp., arī fonētiskās un varbūt dažas iespējamās morfoloǵiskās, izmaiņas, par kurām to apjoma, dažādības un neskaidrības dēḷ jārunā atsevišksi.

\section{Materiāla apjoms un pētniecības metode}

EE2 no EE1 struktūriski neatṣ̌̌iras - abos krājumos ir tās pašas 147 norādes uz lasījumiem vai 146 perikopes (73 evangéêliju un 73 epistulu izvilkumi). Pa vidu tām ielikta pasija jeb Kristus ciešanu stāsts, kas uzskatāma par atsevišksu daḷu, tāpēc pētījumā netika ieklạuta. Abi perikopju teksti ņemti no Latviešu valodas seno tekstu korpusa ${ }^{8}$ un salīdzināti, izmantojot automātiskās salīdzināšanas programmu ${ }^{9}$. Rezultātā iegūts šāds teksts ar identificētām izmainุām (izsvìtrotais teksts EE2 nav iekḷauts, bet pasvītrotais - EE2 pievienots):

Die Epiftel auff den $\forall \underline{V}$ ierden Son-tag des Aduents Phillip. 4. €ㅁapit. MYlige Brale / preczeetes yums exkan to kunge allaßin / vnde whel wene kärtattre ßacke es / preceeczates yums / Juule Laipnỵibe laideth Binnamme buuth wteü[fims czilwhekims / Tas kKunx gir tuwe klathe / Nhe gadayeth neeneke [..].

Manuāli apkopojot un sagrupējot visas fiksētās izmaiņas, tās, gandrīz tāpat kā Georga Manceḷa LVM gadījumāā ${ }^{10}$, var iedalīt sešās izmaiņu grupās (dažas dalot arī sīkāk): 1) rakstības, 2) morfologiskās: 2.1.-precizējumi un 2.2. - citas izmaiņas, 3) vārddarināšanas, 4) leksiskās, 5) sintaktiskās un 6) izmaiņas panta struktūrā: 6.1. - pielikumi un 6.2. - izlaidumi. Lai gan, kā iepriekš teikts, tālāk rakstības izmaiņas netiks aprakstītas, 1. diagrammā aplūkojams visu izmaiņu sadalījums EE, tostarp arī rakstības.

\section{Morfologíiskās izmaiņas}

Par izmaiņām morfolog̣ijā EE rakstības dēḷ runāt ir sarežg̣īti. Kā redzams 1. diagrammā, tās šajā pētījumā nosacīti iedalītas divās grupās: galotņu precizējumos (2.1.), kas ir saistīti ar ortogrāfiju, un citās izmaiņās (2.2.). EE1 savdabīgās rakstības dēḷ bieži ir grūti noteikt, vai vārdā ir veikta izmaiņa vai tas ir tikai precizējums, it īpaši tad, kad EE1 izmantota grafēma <e>, piem., Gode gir Dewam $\rightarrow$ Gods gir Dewam. Lìdz ar to pētījums iegūst subjektīvu nokrāsu,

\footnotetext{
${ }^{8}$ http://www.korpuss.lv/senie, tomēr teksti salīdzināti ar oriǵinālu un pārbaudīti.

9 https://www.ddginc-usa.com/text-compare-tool.htm

10 Sk. Kazakènaite 2017.
} 
jo tālāk tiks aplūkotas tādas morfolog̣iskās izmaiņas, kas šķiet neapšaubāmas, uzsvaru liekot uz citām morfolog̣iskajām izmaiṇām. Lai iekḷautu arī iespējamās izmaiņas, jāveic atsevišşss pētījums.

2.1. Neskatoties uz neskaidrībām, nosacīti par galotṇu precizējumiem ir iespējams runāt, un, kā redzams 1. diagrammā un 1. tabulā, tas ir otrs biežākais tips - sastopams 58 (34 evangêeeliju un 24 epistulu) perikopēs. Ar jēdzienu precizējums ir domāta izskaņas, kurā ir - $e$ - vai $-i-$, nomaina pret kādu citu, piem.: wueffes czilwhekes abfkaydro $\rightarrow$ wuffos czilwhekus abfkaydro (Jn 1:9); es gode Manne Thewe $\rightarrow$ es Göda Manno Thewu (J̣n 8:49); Vnde tur by Ganne $\rightarrow$ Ganni (Lk 2:8); queeleines Ogles $\rightarrow$ queeleinas Oglis (Rm 12:20); peetcz trims denims $\rightarrow$ peetcz trims denams (Lk 2:46). Jāteic, ka tās ir pa vidu starp rakstības un morfolog̣iskajām izmaiņām, bet, tā kā robeža ir blāva un rakstības izmaiņas šajā rakstā plašāk netiek aplūkotas, tās analizētas pie morfoloǵiskajām izmaiņām (sk. arī Augstkalns 1930: 102).

Nepieciešamība šiss izmaiņas atspoguḷ ot radās tāpēc, ka bieži vien agrākajos pētnieku darbos (sk. Augstkalns 1930: 102; 1934: 13; Ozols 1965) minēts uzskats - EE valoda esot kḷūdaina un aplama tieši lietotās grafēmas $<\mathrm{e}>$ dēḷ, kas aizstāi citus patskaņus (Augstkalns 1933: 42). Arī Jānis Endzelīns (1951:20-21) ir teicis, ka EE l̦ loti neprecīzā rakstība mazina to vērtību. Taču EE2 vērojama tieksme precizēt vārdu galotnes un atspoguḷot arī citus patskaņus. Tomēr 1. diagrammā var labi redzēt, ka šis apgalvojums attiecas tikai uz daļu no krājuma perikopēm - galotnes precizētas lielākoties perikopju krājuma pirmajā pusē (apmēram līdz 80. perikopei (Jñ 10:1-11)) un arī beigās. Grūti pateikt, kāpēc tā ir, var tikai minēt, ka tas atspoguḷ EE1 rediǵēšanas vēsturi-pārējās daļas labotas mazāk. To apliecina arī citu veidu izmaiņas, kuru otrajā dạ̧āa ir mazāk, izņemot izlaidumus, taču tie bieži vien ir neapzinātas maiņas jeb korektūras kḷ̂̄das.

2.2. Citas morfoloğiskās izmaiņas vērojamas 35 (22 evaņgēeliju un 13 epistulu) EE perikopēs (sk. 1. diagrammā 3. tipu). Tās vairāk sastopamas darbības vārdos (2.2.), nevis nomenos (2.1.), pretēji, piemēram, G. Manceḷa veikto izmaiņu virzienam (sk. Kazakènaitė 2017: 11).

2.2.1. N o m e n o s visbiežāk notikusi dzimtes kategorijas maiņa virzienā vìr. $d z . \rightarrow$ siev. $d z$. (a), bet divreiz arī otrādi (b).

a) vīr. $d z$. $\rightarrow$ siev. $d z$. maiņas piemēru lielāko daḷu veido vietniekvārdi daudzskaitlī: vnd py tems effzams / to Libien $\rightarrow$ vnde py thäms effzams / tho Libier (Apd 2:10); thos kayes mafgath / vnd Boufenaye thos $\rightarrow$ thäs kayes maßgath / Vnde ßoufenaye thas (Jṇ 13:5); tös kayes $\rightarrow$ thäs kayas (Jṇ 13:8, 9, 10, 14); tös Auwes $\rightarrow$ täs Auwis (Jņ 10:3,12); tims Auwims $\rightarrow$ thäms Auwims (J̣n 10:11,15). Tas nepārsteidz, jo savulaik jau J. Endzelīns ir 
pamanījis, ka šādu vīriešu dzimtes formu lietošanu daudzskaitlī ir ietekmējusi vācu valoda, un EE2 tās labotas kā interferences kḷūudas. Šķiet, vienreiz šāda virziena dzimtes maiņa notikusi arī lietvārdā: Beth pär to wueffe apwelcet to mylibe / katteers tur gir tas Saytcz täs puelnibes $\rightarrow$ Katters tur gir tha Sayta thas pülnibes (Kol 3:14).

b) siev. $d z$. $\rightarrow$ virr. $d z$. maiņa vērojama tikai vienskaitlī, saskaņotajā apzīmētājāa un vietniekvārdā, kas lietots artikula funkcijā: Es efme wena foutctzamme balexnis wene Maetczetaye $\rightarrow$ Es efme wens fouctzams balxnis wene Maetczetaye (Jn 19:23); wena Balxnis no Debbeffe ßatcy $\rightarrow$ wens Balxnis nho Debbeffe ßatcy (Mt 3:17), bet pārējos divos gadījumos - Apd 2:6 un Jes 40:3 - arī EE1 balxnis tiek lietots kā vīriešu dzimtes vārds. Abos piemēros sieviešu dzimtes lietošanu, iespējams, ir ietekmējusi arī vācu valoda (sal. die Stimme).

Viena maina EE2 - ka thas ftippre ftawhet war $\rightarrow$ ka ta Jtippre Jtawhet war (Zīr 15:4) $)^{11}$ - arī izskatās kā vārda dzimtes mainīšana, tomēr visdrīzāk tā ir korektūras kḷūda, jo dzimtes maiņu nepamato neviens no avotiem: subjektam jābūt vīriešu dzimtē, nevis sieviešu.

Citu tipu izmaiņu nomenos ir maz. Trīsreiz vācu valodas ietekmē EE1 lietotā dsk. 3. personas lokāmā piederības vietniekvārda vietā EE2 lietots nelokāmais: Beth tas no mannie winges domafchennes $\rightarrow$ Beth tas no mannye wingu domafchennes (Lk 11:17) ${ }^{12}$; vnde ladeye winge neetitczybe / vnde winges Byrdefcetybe $\rightarrow$ vnde ladeye wingu neetitczibo / Vnde wingu Birdefcetibe (Mk $16: 14)^{13}$. Tomēr vēl deviņos gadījumos pārējās perikopēs šì vietniekvārda forma atstāta bez izmaiņām.

Vienreiz EE1 un EE2 atškiras arī īpašvārda rakstība: vnd py tems effzams / to Libien $\rightarrow$ vnde py thäms effzams / tho Libier (Apd 2:10). EE2 lietotajam Libier pamatojuma avotos citās valodās nav, jo $-r$ neparādās ${ }^{14}$ : LB, LBž - Lybien; $\mathrm{GR}-\tau \tilde{\eta} \varsigma \Lambda \iota \beta \dot{v} \eta \varsigma ; \mathrm{V}-$ Lybiae.

Atsevišķi jāpiemin EE1 un EE2 atšksirības illatīva formu rakstībā. Lai gan gramatikās un citos darbos tiek runāts vien̄igi par formantu -n (Augstkalns 1933: 47; Endzelīns 1951: 460-461; Ozols 1965: 84; Rosinas 2005: 121), EE2 tas piecas reizes nomainīts pret $-m$ (a), bet sastopami arī pretēji gadījumi, kad EE1 lietots $-m$, savukārt EE2 $--n(b)$ :

${ }^{11}$ LBž - Dadorch wert he stark werden / dar he vaste stan kan [..]; LB - Da durch wird er starck werden / das er fest stehen kan [..]; LVM1 - Czaur to tas Jtippris kluß / ka tas ftippre ftaweht warr [..].

${ }^{12}$ LBž - He vornam auerst ere gedancken [..]; LB - Er aber vernam jre gedancken [...]; LVM1 - Bett wings nomanniya winjo Dohmas [..].

${ }^{13}$ LBž - [..] Vnde schalt eren Vngelouen / vnde eres herten hardicheit [..]; LB - [..] Vnd schalt jren vnglauben / vnd jres hertzen hertigkeit [..]; LVM1 - [..] vnd lammaya winjo Nhetitzibu / vnd winjo Śirrtz czeetumu [...].

${ }_{14}$ Piem., G. Mancelis un pārējie 17. gs. autori lieto py teems Efcheems to Lybieṛo. 
a) thas yums paauxtena ßouwan laykan $\rightarrow$ thas yum $\beta$ paauxtena ßouwam laika (1Pēt 5:6); kopan bye $\rightarrow$ kopam bye (Mt 22:41); loudes wenan kopan by $\rightarrow$ loudes wenam kopan by (Lk 8:4); nhe näckJem prefchan $\rightarrow$ prexfcham (1Tes 4:15); parradan $\rightarrow$ parradam (Mt 18:24);

b) Semmem nätcis $\rightarrow$ Semmen nätcys (1Tes 4:15); parradam $\rightarrow$ parradan (Rm 13:8); wuerfom $\rightarrow$ würßon (Lk 21:35); tefcham $\rightarrow$ tefchan (Tit 3:8).

Vispār illatīva formas ar $-m$, spriežot pēc valodiskajiem aprakstiem, valodā nav bijušas sastopamas, tāpēc jādomā, ka tāda maiņa radusies nejauši: $-n \rightarrow-m$ maiņa kā drukas kḷ̂̄das burtu $m$ un $n$ līdzīguma dẹl vai arī pēc analog̣ijas pārceltas, piem., no apstākḷa vārdiem kā augšām vai tiešām, bet $-m \rightarrow-n-$ kā EE1 korektūras kḷūudu labojumi (iznemot tefcham). Kḷūdas, nevis kādas paralēlas formas iespējamību apliecina fakts, ka to lietojums ar - $m$ ir okazionāls, jo citās vietās sastopam illatīvu tikai ar formantu -n, piem., kopan (14), wenan (3), parradan (8) utt.

2.2.2. Atsevišķ kielu grupu veido maiņas $\mathrm{d}$ a r bīib a s vārdos - to ir vairāk nekā nomenos. Divreiz EE2 mainīta darbības vārda izteiksme: ka tas bherns apgreftz tapte / tad tappe winge wärdtcz dheweetcz Jefus $\rightarrow$ ka tas Bherns apgreftz tappe / Tad tappe winge wärdctz dhe weetcz JEfus (Lk 2:21) ${ }^{15}$; ka tas no tho Whelne kärdenaatz tapte $\rightarrow$ Ka thas nho tho Whelne kärdenaatz tappe (Mt 4:1) ${ }^{16}$. Abos piemēros ir līdzīga maiņa - verbs tapt vēelējuma izteiksmē, kas visdrīzāk lietots Lutera Bībeles ietekmēe, nomainìts pret īstenības izteiksmi. Lk 2:21 tāda maiņa ir pamatota, jo teikums izsaka pabeigtu darbību, kas īstenojas (vispirms apgreftz, tad dheweetcz), tomēr Mt 4:1 vēlējuma izteiksme būtu piemērotāka, jo tiek runāts par iemeslu-TAd tappe Jefus no Garre exkan to Tuxniffe wheftz / ka tas no tho Whelne kärdenaatz tapte.

Grūti pateikt, bet ir iespējams, ka bijusi vēl viena šā tipa maiņa: nhe ßinnaya no kurrenes thas naeckte $\rightarrow$ nhe ßinnaya no kurrenes thas näcktze (Jñ 2:9) ${ }^{17}$. Te neskaidrības rada ortogrāfija un arī tas, ka vārdforma naeckte EE1 (resp. näcktze EE2) tādā rakstībā sastopama tikai vienreiz. Viens no EE2 näcktze skaidrojumiem varētu būt tāds, ka maiņa radusies, jo kāds virs vārda vai blakus uzrakstịijis labojumu, bet burtlicis nav sapratis un uzrakstījis visus līdzskaņus kopā. ${ }^{18}$

${ }^{15}$ LBž - [..] dat dat Kindt besnëden wörde [..]; LB - [..] daß das Kind beschnitten würde, da ward sein Name genannt Jesus [...]; LVM1 - [..] ka tas Bährns apgreefts taptu [..].

${ }^{16}$ LBž - [..] Vp dath he vam Dünel vor socht worde; LB - [..] Auff das er von dem Teuffel versucht würde; LVM1 - [..] ka tas no to Wallu kahrdenahtz taptu.

17 LBž - [..] vnde wüste nicht wor he her quam [..]; LB - [..] vnd wuste nicht von wannen er kam [..]; LVM1 - [..] vnd nhe finnaya no kurrenes tas nahze [..].

18 Zināms, ka, gatavojot EE1 Kēnigsbergā, bijis kāds korektors (Augstkalns 1930:97). Tāds varētu būt bijis, arī gatavojot otro izdevumu, jo ir vēl daži piemēri, kā šis - es gode Manne Thewe / vnde yuus neegodeth man $\rightarrow$ es Göda Manno Thewu / vnd yuus negodaeth man (J̧̦ 8:49), kurā, škiet, arī labojums varētu būt bijis uzrakstīts virs vārda, lai precizētu darbības vārda izskaņu. 
Verbs nākt EE2 nomainīts vēl vienā vietā: Jefus nake $\rightarrow$ JEfus näcze (Jņ 20:26). Abas formas - gan bez līdzskaņu mijas, gan ar to - pārmaiņus tiek lietotas abos perikopju krājumos itin bieži.

2.2.2.a. Kā arī būtu gaidāms, ņemot vērā Jāņa Kušksa secinājumus par dažādām dialektālajām pirmo rakstu pieminekḷu pazīmēm ${ }^{19}$, vairākās vietās iespējams saskatīt vienas izlokšņu formas maiņu pret otru. Ne reizi vien EE meklētas lībiskā dialekta pēdas (K. Mīlenbahs, J. Kušksis), tomēr secināts, ka lielā pārsvarā tekstos ir vidus dialekta izloksnēm raksturīga morfoloǵija (Kušksis 1998: 76), izņemot darbības vārdu 3. personas formu lietojumu. Tieši 3. personas formās, kas lībiskajā dialektā lielākoties vispārinātas (Rudzìte 1964: 231) un lietotas arī 2. personā, fiksētas izmaiņas, piem., thad tu queeleines Ogles wuerßon wynge Galwe ßakraas $\rightarrow$ Tad tu queeleinas Oglis würßon wynge Galwe ßackrafi (Rm 12:20) un tu taps apgrutenata exkan meße / vn wene Dhele peczimps $\rightarrow$ tu taps apgrutenata exkan meße / vnde wene Dhele peczimpfi (Lk 1:31); vnde es Abraham redtczeis ? $\rightarrow$ vnd effi Abraham redtczeis ? (Jņ 8:57) (sk. arī Rudzīte 1964: 232). Tomēr fiksēts arī pretējs piemērs, kad viena iespējamā vidus dialekta forma, mainot verbu īstenības izteiksmē pret pagātnes aktīvo divdabi, nomainīta pret iespējamo lībiskā dialekta formu - the gyr wene wayge tho Engel redtczeifche / katters tur ßacke / tas cziwo $\rightarrow$ Thä gir wene wayge tho Engel redtczeifche / katters tur ßatczifch / thas cziwo (Lk 24:23)20. Šajā piemērā pagātnes divdabis sacīijs tiek lietots ar notikušo asimilāciju $(-\check{s}<-j s<-j i s)$, kas ir raksturīga dalıai lībiskā dialekta izlokšñu (Rudzīte 1964: 184, 189, 250). Ja nākamajā piemērā tā nav kḷūda, ir vēl viena šāda izlokšnu formas maiņa: mums nhe gir newens $\boldsymbol{\beta}$ adderreis $\rightarrow$ mums nhe gir newens $\boldsymbol{\beta}$ adderres (Mt 20:7) ${ }^{21}$. Tomēr grūti noliegt korektūras kḷ̂̄das iespējamību, jo vārdiem atšksiras tikai viens burts vārda beigās.

Patiesībā ir vesela virkne verbu, kas EE1 un EE2 atškiras tikai ar vienu beigu burtu: winge Engele czyxteye $\rightarrow$ winge Engele czyxtey (Atkl 12:7); the fthaweye $\rightarrow$ the fthawey (Lk 17:12); es $\boldsymbol{\beta}$ acke yums $\rightarrow$ es $\boldsymbol{\beta a c k}$ yums (Jṇ 8:58) un thas pallecke $\rightarrow$ tas palleck (Jñ 21:22) (Rudzìte 1964:235, 239). Tomēr jāpiebilst, ka vērojama tikai - $e$ atmešana, nevis pielikšana, un visi verbi ir īstenības izteiksmē. Šāda bezgalotnes formu rakstīšana ir raksturīga dažādām izloksnēm, kurās notikusi redukcija (Rosinas 2005: 113). Arī nākamais piemērs radies tāpēc, ka vienlaikus pastāvējušas vairākas formas - Vnde kad

${ }^{19}$ Iespējams, ka Rīgas latviešu valodā 16. gs. vienlaikus bija sastopami gan vidus, gan jaunā lïbiskā dialekta elementi (Kuškis 1996: 80).

20 Šajā piemērā redzamā the $\rightarrow$ Thä maiņa nav skaidra, jo EE2 Thä tiek lietots tikai vienā gadījumā. Citviet atrodams tikai tä, piem., Exkan tho wärde tä Kunge (Mt 21:9), tomēr arī tikai vienu reizi.

${ }^{21} \mathrm{LBž}-[.$.$] vns hefft nemandt gemedet [..]; LB - [..] Es hat vns niemand gedinget [..]; LVM1 - [..]$ Nheweens nhe gir mums śadarreyis [..]. 
tha to attradduffche gir [..] es efme manne Groffche atkal attrad=duffe / kat=tre es paffudduffe by $\rightarrow$ es efme manne Groffche atkal attradduffche (Lk 15:9). J. Endzelīns (1951: 944-945) atzīmē, ka pagātnes aktīvā divdabja sieviešu dzimtes nominatīvs izloksnēs visbiežāk aizstāts ar -se, tomēr, kaut arī retāk, dažviet pēc pārējo locījumu parauga tas pārveidots ar -š-.

Runājot par izlokšñu formām, jāmin vēl daži piemēri: Tad bhege wuerßon tems kalnems $\rightarrow$ Tad bhedzet wuerßon thems kalnems (Mt 24:16)22 un gir $\rightarrow$ yr (1Kor 11:24). EE1 Mt 24:16 tāda forma var būt radusies labošanas rezultātā, jo lībiskajā dialektā indikatīva 3. personas forma nereti izspiedusi arī dsk. 2. personas formu imperatīvā (Rudzīte 1964:231), bet 1Kor 11:24 izmaiņa visdrīzāk ir drukas kḷūda. To apliecina fakts, ka EE1 lietotais gyr EE2 nomainìts uz gir pat 16 reizes, bet forma $y r$ vispār sastopama tikai šo un vēl vienu reizi, kad sakrìt arī ar EE1 (tha neeaugliga yr).

2.2.2.b. Divreiz EE2 mainīta primāra darbības vārda sakne, kas EE1 apzīmēta ar $\langle\mathrm{e}\rangle$ : Wena Sewe / kad tha czem / tad gir tay no/kum/chenne $\rightarrow$ Wena Sewe / Kad tha czim / tad gir tay nofkum/chenne (Jn 15:21); katters py kalpofchen peczem $\rightarrow$ peczim (Gal 4:24), tomēr vēl Lk 2:23 pantā tā ir atstāta nemainīga (peczem). Interesanti, ka, lai gan Gal 4:24 pantā maiņa fiksēta, tai pašā lappusē ir arī šāda maiņa - tu nhe czeem $\rightarrow$ tu nhe cziem (Gal 4:27). Tam var būt dažādi skaidrojumi, bet viens no iespējamiem (ja labojums tika rakstîts virs burta, nosvìtrojot to), ka tāda sakne radusies, jo burtlicis pārpratis burtu maiņu. Tomēr uzreiz jāpiebilst, ka EE1 ie tādā rakstībā vārda saknē ir retums, izņemot gadījumus, kad lietots gaidāmā $j$ vietā (v/iemt, ieb), taču EE2 tas nomainīts vēl dažos citos vārdos: Tetczibe $\rightarrow$ Tieczibe, Wefe $\rightarrow$ Wiefe un Swefte $\rightarrow$ Swiefte.

2.2.2.c. Dažas izmaiņas l̦auj runāt par laika kategorijas maiņu, piem., THa gir Dews to Paffoule pemileys / ka thas ßouwe wenige Dhele doeuwe / ka wueffe the kattre exkan to titcz / nhe thope paffufte / beth to mußige cziwo/chenne dabbu $\rightarrow$ beth to mufige cziwofchenne dabbuy (Jṇ 3:16) ${ }^{23}$. EE1 lietotā tagadne ir pārtulkota no Lutera Bībeles, jo GR un V pantā - vēlējuma izteiksme, tomēr tās nomaiņai uz pagātni cēlonis nav skaidrs. Citā vietā, arī Jāņa evaņgêelija pantā, darbības vārds mainīts uz nākotni: beth tas Layx nake / ka es nhe wayrs czour lydtczibems ar yums treffeefcho $\rightarrow$ beth thas Layx naks / Ka es nhe wayrs czour

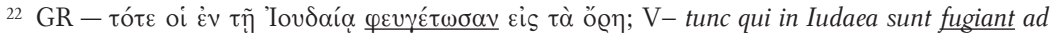
montes; LBž - Denne flege vp de Berge / wol im Jödeschen lande ys; LB - Als denn fliehe auff die Berge / wer im Jüdischenlande ist; LVM1 - Tad laid bähg wirfśon teems Kallneems / kas Juddo=Semmeh gir.

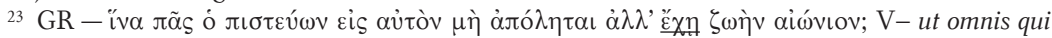
credit in eum non pereat sed habeat vitam aeternam; LBž - Also hefft Godt de Werlt geleuet I dat he synen eynigen Söne gaff / vp dat alle / de an en gelöuen / nicht vorlaren werden / sunder dat ewige Lönendt hebben; LB-ALso hat Gott die Welt geliebet / das er seinen eingeboren Son gab / Auff das alle die an jn gleuben / nicht verloren werden / sondern das ewige Leben haben. 
lydtczibems ar yums treffeefcho (J̧̧ 16:25) 24. Arī šai izmaiņai nav pamata, skatoties iespējamos oriǵinālavotos, jo visos šajā vietā tiek lietota tagadne, bet pēc konteksta izmaiņa ir piemērota - tā tika saskaņota ar palīgteikumu (treffeefcho).

İstenības izteiksmes tagadnes formas maiņa uz nākotni fiksēta vēl vienā vietā. Varbūt arī šajā piemērā ir jārunā par izteiksmes maiṇu - To darreth / czekärth yuus to ferreth / py manne peminnefchenne $\rightarrow$ Tho derreth / czekärth yuus to czerSeth / Py manne peminnefchenne (1Kor 11:25)25. Tomēr nākamajā pantā ir tieši otrādi - Aefto czekärth kha yuus no fcho Mayfe ehdath / vnde no fcho Bickere czerfeth / buus ynms ta Kunge Nawe paßluddenath $\rightarrow$ Aifto czekärth kä yuus no fcho Mayfe ehdath / Vnde nho fcho Bickere czerreth / buus yums ta Kunge Nawe paßluddenath (1Kor 11:26) ${ }^{26}$. Jāpiezìmē, ka 1Kor 11:26 pantā EE1 lietotā tagadne šajā teikuma vietā neliekas piemērota, bet EE2 tas labots un pieskaņots ehdath.

Vienreiz EE1 verbs 1̄stenības izteiksmes tagadnē EE2 nomainìts pret nenoteiksmes formu: tha buus ta Czilwheke Dhelam patczeltam tapt / Ka wueffe / kattre exkan to titcz / nhe thope pa=fufte / beth to mußige cziwo/chen dabbuu $\rightarrow$ dabbut (Jņ 3:14-15) 27. Tādu maiņu nav viegli izskaidrot, jo tā šķiet nepamatota, bet var būt, ka tas ir pieskaņots saliktā teikuma pirmajai daḷai (sk. pasvītroto).

\section{Vārddarināšanas izmaiṇas}

Izmaiņu vārddarināšanā nav daudz, tās vērojamas 16 (8 evanggéeliju un 8 epistulu) perikopēs. To mazliet vairāk ir verbos (3.1.) nekā nomenos (3.2.).

3.1. Darbības vārdos veiktas gan prefiksālas, gan sufiksālas izmaiņas. Te četras reizes mainīts verba priedēklis (pie-; no-; ie-; pār-): vienreiz pielikts klāt-kad the czeeruffche tappuffche gir / ka tad to planako $\rightarrow$ kad the Peczeeruffche tappuffche gir / tad tho planako (Jņ 2:10); divreiz atmests - nätce

${ }^{24}$ LBž - [..] De tydt kümpt auerst / dat yck nicht mehr dorch Byspröke mith yuw reden werde [..]; LB - [..] Es kompt aber die zeit / das ich nicht mehr durch Sprichwort mit euch reden werde [..].

${ }^{25}$ LBž - [..] Sölckes döth / so vaken alse gy ydt drincken / tho myner gedechtenisse; LB - [..] Solchs thut / so offt jrs trincket / zu meinem Gedechtnis; LVM1 - [..] to darraita / czeekahrt juhß to dferreeta / mannis peeminnädammi.

${ }^{26}$ LBž - Wente so vaken alse gy van dessem Brode ethen / vnnde van dessem Kelcke drincken / schöle gy des HERen dodt vorkündigen / beth dat he kümpt; LB - DEnn so offt jr von diesem Brot esset / vnd von diesem Kelch trincket / solt jr des HErrn tod verkündigen / bis das er kompt; LVM1 - Aifto czeekahrt juhß no fcho Mais ähdäht / vnd no fcho Bickeri dferraht / buhß jums tha Kunga Nahwes pafluddenaht / teekams tas nahk.

${ }^{27}$ LBž - [..] Also moth des Minschen söne vorhöget werden / vp dat alle / de an en gelöuen / nicht vorlaren werden / sunder dat ewige lëuent hebben; LB - [..] Also mus des menschen Son erhöhet werden / Auff das Alle die an jn gleuben / nicht verloren werden / Sondern das ewige Leben haben; LVM1 - [..] ta buhß tha Czillwäka Dählam pa=auxtenatam tapt ka wifśi / kattri eekJchan to titz / nhe tohp pafuddufchi / bett to muhfchigu dfiewofchanu dabbu. 
tuwe prexkan to Jelgouwe / kur the nogaya / Vnde thas thurreya ßöw $\rightarrow$ nätce tuwe prexkan to Jelgouwe / vs kattre the gaya / vnde thas weerßes ßöw (Lk 24:28); Es ßack yums / kas czour to Durwe nhe e eth / exkan to Auwekuute $\rightarrow$ Es ßack yums / kas czour tho Durwe nhe eth / Exkan to Auwekuute (Jn 10:1); vienreiz

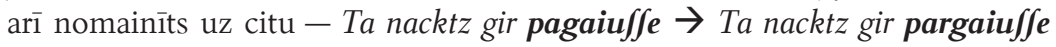
( $\mathrm{Rm}$ 13:11). Tomēr pilnīgi iespējams, ka abos pēdējos piemēros - nhe e eth : nhe eth un pagaiuffe : pargaiuffe - izmaiñas ir neapzinātas.

Formāli skatoties, priedēklis ie- EE2 pielikts klāt arī šai piemērā: Vnde thas yeme thos Sep=tinge Mayfes / vnde patteitcze / vnde pär loufe thos / vnde doeuwe thos ßouwims Maetceklims $\rightarrow$ Vnde tas yeme thos Septinge Mayfes / vnde patteitcze / vnde pär loufe thos / vnd e döuwe thos ßouwims Maetceklims (Mk 8:6). Tomēr te, visticamāk, ir drukas kḷūda - nevietā ielikta atstarpe, jo EE1 lietots vnde EE2 atbilst vnd, lai gan bieži pilnīgi pretēji-EE1 sastopamais vnd EE2 nomainits pret vnde.

Divreiz mainits verba atgriezeniskums: vienreiz atmests refleksīvais afikss sa-: J $\beta$ abrinoyas the ßöw / vnde teytcze $\rightarrow$ IJzbrynoyas fzöw / Vnde teytcze (Mt 9:8), bet vienreiz tiešs darbības vārds nomainīts pret atgriezenisko: Kad nu touwam enaidenekam Jßalckeft / thad baryo tho / Twyxth tham / thad cziyrdena to $\rightarrow$ Kad nu touwam enaidenekam Jßalckas / Thad baryo tho / Twyxth tham / tad czirdena to ( $\mathrm{Rm} 12: 20)$.

Interesanti, ka plaši aprakstītā vārda dabūt jauktā paradigma latviešu izloksnēs (sk. Endzelīns 1951:843-844) atspoguḷıjas arī izmain̄ās: dabbauuth $\rightarrow$ dabbuith (Apd 10:43); dabbuthe $\rightarrow$ dabbuithe (Apd 8:15); mhes czour patczefchenne / vnd precibe to Raxte / wene Czerribe dabbuyam $\rightarrow$ dabboyam (Rm 15:4). Tās liecina, ka paradigma bijusi jaukta arī 17. gs. sākumā.

3.2. Li e tvārdu vārddarināšanas izmaiņas jādala divās grupās, jo daḷāa vārdu izmaiņas ir ļoti apšaubāmas. Par neapšaubāmām izmaiņām var runāt, ja mainīts lietvārda piedēklis: vienreiz tas mainìts pret citu - exkan ßaltyhe vnd $\underline{\text { nodzibe }} \rightarrow$ exkan $\beta$ altum vnd Kailum (2Kor 11:27), bet divreiz atmests - tad pa yem thas tham wynge Brunnige $\rightarrow$ Tad pa yem thas tham winge Brunnyias (Lk 11:22); ßeneth to exkan naftinims $\rightarrow$ Beneth to exkan naftams (Mt 13:30). EE1 vārds bruñas biežāk lietots bez piedēkla -ig- (Brunye; 6) un tikai divas reizes ar piedēkli. Tāpat arī nasta EE sastopama bez deminutīva piedēkḷa -iṇ-, izņemot citēto piemēru.

Pārējās izmaiņas lietvārdu vārddarināšanā jāmin kā apšaubāmas, jo vārdi EE1 un EE2 atškiras tikai ar vienu vai diviem burtiem, piem., varbūtēja priedēkḷa maiņa (varbūt precizējums) - peßatcifchenne $\rightarrow$ paßatcyffchenne (Apd 13:31) - vai vienā vietā pielikts piedēklis - n- - Attraite $\rightarrow$ Attraitne (Lk 2:37) -, kas citviet atstāts bez izmainām (attraites Jk 1:27), bet vēl vienā vietā EE1 sastopams ar piedēkli (Lk 7:12). Iesprausti arī daži patskaņi, 
piem., ftarpan thems Raxtmaet $=$ cetayems $\rightarrow$ ftarpan thems Raxtimaetce $=$ tayems (Mt 9:3) vai by=fchenne $\rightarrow$ bya chenne (1Jņ 4:18). Pēdējais piemērs iespējams ir EE1 drukas kḷ̂ùa, jo iepriekšèjā tās pašas perikopes EE1 rindiņā līdzīgs vārds, kas nav pārcelts uz nākamo rindinu, ir Byafchenne. Tātad tas var būt arī nejaušs izlaidums, tomēr par šo - meckle duffefchenne $\rightarrow$ meckle duffchenne (Lk 11:24) - tā apgalvot ir grūti, jo izlaisti divi burti, kas liek domāt, ka tiem varētu būt cits pamatvārds: pirmatnējs dust un atvasinātais $d u s \bar{e} t$.

\section{Leksiskās izmaiņas}

Izmaiņas leksēmu izvēlē fiksētas 28 (13 evaņgêeliju un 15 epistulu) perikopēs. Tomēr arī šai grupā ne visas ir uzskatāmas par īstām - vārdi bieži vien avotā atšksiras tikai ar vienu burtu, kas liek domāt, ka tās varētu būt korektūras kḷ̂udas.

4.1. Šādas apzinātas un neapzinātas izmaiņas vērojamas s a i k ḷ u nomaiṇā, piem., vietām sajaukti burti vārdam piešksir arì citu nozīmi - $k a$ Chriftus no tims muerronims vs modenaatz / un nhe wairs muer/t $\rightarrow$ Ka Chriftus nho thims mürronims vs modenaatcz / nu nhe wayrs mürft (Rm 6:9), tomēr nākamie divi piemēri ir îsti stilistiski labojumi:lelotes / beth wene mannes waybes $\rightarrow$ lelothes / Ka wen mannes waybes (2Kor 12:5) un Beth yuus buufeeth nofkummuffche / beth yuufe nofkumfchenne buus pär preczybe tapt $\rightarrow$ Vnde yuus buufeeth nofkummuffche I Beth yuufo nofkumfchenne buus pär preczibe tapt (J̦ 16:20).

Nav īsti skaidrs, bet varbūt šai grupā ierindojas arī šì maiņa - Tad ßatcy the / kas gir tas ka tas ßack / pär wene maße bryde? $\rightarrow$ Thad ßatcy the / kas gir thas ko tas ßack / pär wene maße bryde? (Jṇ 15:18). Ja tā ir apzināta, tas varētu liecināt par saikḷa $k a$ nomaiņu uz attieksmes vietniekvārdu, kas arī izsaka pakārtojuma sakaru. Tomēr tā var būt arī drukas kḷ̂uda, jo iepriekšèjā pantā esošajā līdzīgā konstrukcijā nekas nav mainìts: Kas gir tas / ka tas vs mums ßacke (Jñ 15:17).

Lielāko atseviškso daļu veido vārda kad maiņa - kopā 7 reizes. Lai gan zinātnieku viedokḷi dalās - tas ir saiklis vai apstākḷa vārds (sk. Paegle 2003: 221; LLVMSA: 206-212) -, turpmāk sniegtajos piemēros kad visdrīzāk būtu uzskatāms par saikli. EE2 kad piecas reizes nomainīts pret saikli ka: Szuuty the py tems Petrum vnde Johannem / kattre / kad the Semmen nätce / luudtcze the pär thems $\rightarrow$ kattre / ka the Semmen nätce / luudtcze the pär thems (Apd 8:18); thas noticke / $k$ ad the nogaye $\rightarrow$ tas noticke / $k$ a te nogaye (Lk 17:14) ${ }^{28}$; Kad thas nu exkan to Helle / vnde exkan to moke by $\rightarrow$ Kha thas nu exkan to Helle vnde exkan to moke by (Lk 16:23); BEth prexkan tho fweetke to leledene

${ }_{28} \mathrm{LBž}-[.$.$] Vnde ydt geschach / do se hen gingen / würden se reyne; LB - [..] Vnd es geschach / da$ sie hin giengen / worden sie rein; LVM1 - [..] Vnd tas notickahß kad tee noghaya / tappa tee Jkiefti. 
kad Jefus at Bynne / ka winge layx nätczis by / ka thas aran fcho Paffoule edth py Thewe $\rightarrow$ BEth prexkan to fweetke tho leledene $\boldsymbol{k a}$ JEfus atßynne (In 13:1); ta gir ta ledtcybe Johannis / kad te Judde no Jerufalem Bafnicekunges vnd Leuites futy /

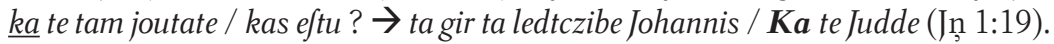
Tomēr divos gadījumos kad mainīts pret kas - kad tas layx nätcys $\rightarrow$ Kas tas layx nätcys (Jñ 16:4) vai kad es no to Ammatte no celtz thope $\rightarrow$ Kas es nho to Ammatte nho czeltz thope (Lk 16:4) -, un tās, šksiet, ir drukas kḷūdas. Vienreiz kad nomainìts pret tad, kas izskatās pēc EE1 drukas kḷūdas novēršanas: kad es man patthe godhete khad nhe gir mans goodtcz neeneke $\rightarrow$ kad es manni patti godhete tad nhe gir mans godtcz neeneke (Jñ 8:54).

Iespējams, arī ta nomainai pret tad ir līdzìgs cēlonis: tha ßacket / Tam kungam gir thös wayage $\rightarrow$ thad ßacket / tam Kungam gir tös wayage (Mt 21:3)29; vnde ta ehde tas no fcho Mayfe $\rightarrow$ Vnde thad ehde tas no fcho Mayfe (1Kor 11:28) ${ }^{30}$. Te apstākḷa vārda tā lietošanu EE1 citi avoti nepamato.

Par neapšaubāmi apzinātu a pstā kḷ a vārda izmaiņu jāuzskata tikai šì Lūkas evaņgêlija pantā: tad thope peetcz ar to patte czilwheke nickmake nhe ka paprefche $\rightarrow$ nhe ka pirmack (Lk 11:26) ${ }^{31}$, kurai, iespējams, ir bijis stilistisks iemesls.

4.2. Sešas reizes EE2 nomainīts viet ni ekvārds, tomēr četras no tām atkal atškiras tikai ar vienu burtu un, ņemot vērā citvalodu avotus un kontekstu, drīzāk izskatās pēc drukas kḹūas nekā pēc labojuma: Beth exkan wueffims letims $\rightarrow$ Beth exkan müffims letims (2Kor 6:4); es fuute py Vnde tas noticke I kad tas Whelns yfbroudtce $\rightarrow$ Vnde tad noticke / Kad tas Whelns yfbroudtcze $($ Lk 11:14)32; nu pallecke $\boldsymbol{t a}$ Titczybe $\rightarrow$ nu pallecke $\boldsymbol{k a}$ Tytczibe (1Kor 13:13); es fuute / py yums Prophetes vnd Guddres $\rightarrow$ py mums (Mt 23:34) $)^{33}$. Atsevišķi ¡āmin divi: Beth kad es tös Whelnes czour Beezebub Jfczeno / czour kade Jfczen thös $\rightarrow$ czour Bellzebub Jfczeño / czour ko Jfcen tös (Lk 11:19) ${ }^{34}$ un wuerßon

${ }^{29}$ LBž - [..] so spreket: De Here bedarff erer [..]; LB - [..] so sprechet: Der HERR bedarf ihrer [..]; LVM1 - [..] tad fackaita: Tam Kungam wayaga thäß [..].

${ }^{30} \mathrm{LBž}-[.$.$] vnde also ethe he van dessem Brode [..]; LB - [..] vnd also esse er von diesem Brot [..];$ LVM1 - [..] vnd tad warr tas ähft no fcho Mais [..].

${ }^{31}$ LBž - [..] Vnde idt wert darna mit demsüluen Minschen erger / denn vörhen; LB - [..] Vnd wird hernach mit dem selbigen Menschen erger / denn vorhin; LVM1 - [..] vnd tad pehtz tohp ar to paffchu Czillwäku nicknake / nhe ka pirrmahk.

32 LBž - [..] Vnde ydt geschach / do de Düuel vthuoer [..]; LB - [..] Vnd es geschach / da der Teufel ausfur [..]; LVM1 - [..] Vnd tas notickah $\beta$ / kad tas Wälls ißbehdfe [..].

${ }^{33}$ LBž - [..] Ick sende tho yum Propheten vnde Wyse [..]; LB - [..] Jch sende zu euch Propheten vnd Weisen [..]; LVM1 - [..] es śuhtu py jums Prophetus vnd Ghuddrus [..].

${ }^{34}$ LBž - So yck auerst de Düuele yth dorch Beezebub ythdriue / dorch wene dryuen se yuwe Kinder vth? [..]; LB - So aber ich die Teufel durch Beelzebub austreibe / durch wen treiben sie ewre Kinder aus? [..]; LVM1 - Bett kad es tohß Wällus czaur Beelzebubu ißdfännu / czaur ko ißdfän tad tohß juhfśi Bährni? [..]. 
tems kalnems / kas exkan Judde Semme gir $\rightarrow$ wuerßon thems kalnems / Kattre exkan Judde Semme gir (Mt 24:16) ${ }^{35}$. Tie ir stilistiskie labojumi, kuriem pamats jāmeklē latviešu valodā, nevis jāsaista ar citvalodu avotiem un to atšksirīīām.

4.3. Visdrošāk var minēt v e r b u s, kas mainìti piecos pantos: Tho gir the nokouwu $\int$ che $\rightarrow$ Tho gir te nodeuwu $\int$ che (Apd 10:39) 36; $^{36}$ abdroudye to / tham bye kluffe czefth $\rightarrow$ abdroudye to / Ka tham bye kluffe buth (Lk 18:39); vnde Jslicka tims wueffe raxte $\rightarrow$ vnde platti tims wüffe raxte (Lk 24:27); nätce tuwe prexkan to Jelgouwe / kur the nogaya / Vnde thas thurreya ßöw $\rightarrow$ nätce tuwe prexkan to Jelgouwe / vs kattre the nogaya / vnde thas weerßes ßöw (Lk 24:28); kattre prettibe tho Dwhefel czinyas $\rightarrow$ Kattre prettibe tho Dwhefel czixtas (1Pēt 2:11). Kā redzams, šîs maiņas ir neapšaubāmas, tāpēc jārunā par redig̣ēešanu, bet var tikai minēt, kāds tai bijis iemesls. Tomēr, arī runājot par verbiem, jāmin iespējamās kḷūidas - darreth $\rightarrow$ derreth $\left(1\right.$ Kor 11:24). ${ }^{37}$

4.4. Četras reizes nomainīti arī li e t vārdi : vnde whel wene kärte ßacke es $\rightarrow$ vnde whel wene kattre ßacke es (Fil 4:4), exkan ßaltyhe vnd nodzibe $\rightarrow$ exkan ßaltum vnd Kailum (2Kor 11:27) un Beth no to dhele Dews touws kreeßls palleke no mußibe тußam $\rightarrow$ Beth nho to Dhele Dews touws kreeßls pallecke nho mußige mußam (Ebr 1:8). Pirmais piemērs ir acīmredzama korektūras kḷūda, jo vietniekvārds šajā teikuma vietā nav pamatots, tomēr otrais sasaistās ar citviet četras reizes nomainīto tās pašas saknes ī p a šīb a s vārd u nogs, piem., Es efme Nöx buewis $\rightarrow$ Es efme kails buewis (Mt 25:36,43). Visi četri gadījumi ir tai pašā Mt 25 perikopē. Ebr 1:8 lietvārda mūž̌̉ba nomaiņa uz adverbu mūžr̆gi liekas pamatota, jo citviet EE leksēma mūžìba nevienu reizi neparādās, bet pastiprinājuma konstrukcijā ar mūžam lietots tikai apstākla vārds mūžl̆gi. Iespējams mußibe EE1 radusies kā drukas kḷūda, jo $b$ un $g$ gotiskajā šriftā ir diezgan līdzīgi. Te jāmin arī pretējs piemērs, kad līdzīga drukas kḷūda ir EE2, nevis EE1 - mylige Brale $\rightarrow$ mylibe Brale (Gal 4:28). Te tā paša iemesla dēḷ ir sajaukti burti $g$ un $b$, jo nevienā citā vietā uzrunā mìlība neparādās.

Par burtu sajaukšanu var runāt arī nākamajā piemērā - Töw nhe buus nhe wene wyltige lydtczibe dhot $\rightarrow$ Thöw nhe buus nhe wene wiltige ledtczibe dhot

${ }^{35}$ LBž - [..] denn vörhen.; LB - [..] denn vorhin.; LVM1 - [..] nhe ka pirrmahk.

${ }^{36}$ LBž - [..] Den hebben se gedödet [..]; LB - [..] Den haben sie getödtet [..]; LVM1 - [..] To gir tee nokahwufśchi [..].

37 Sal. Ta yr manna Meße kattra paer yums pär loufta thope / To darreth py manne peminnefchenne. Tha lydtcz arridtczan tho Bickere / Peettz tho wackarre ehdenne / Vnde ßatcy / Schis Bickers gir tas Jouns Eftadyums exkan man ne Affene / Tho derreth / czekärth yuus to czerfeth / Py manne peminnefchenne [...]. 
$(\operatorname{Rm} 13: 9)^{38}$. Tā ir dạ̧a no astotā baušşa, un nevienā agrāk vai arī pēc EE1 izdotā grāmatā nav lietota leksēma lìdzì̉ $a$. Vācu vārds zeugnis vienmēr, pat EE1, tulkots kā liecība, izñemot šo un vēl vienu vietu, bet lìdzība atbilst vācu Gleichnis (retāk Spruch).

4.5. Formāli skatoties, varētu teikt, ka vienreiz EE2 mainìts arī prievārds: Beth te ßhere no to garryge Ackmenne $\rightarrow$ Beth te czhere tho to garrige Ackmeñe (1Kor 10:4) ${ }^{39}$. Tomēr tā ir acīmredzama drukas kḷūda, ko pierāda nevajadzīga vietniekvārda atkārtošana artikula funkcijā.

Par kḷūūu jādēvē arī šāda maiņa: gir wene wußige Werdtczybe $\rightarrow$ gir wene mußige Werdtczibe (Gal 4:25). Te, līizīgi kā iepriekš citētajā 2Kor 6:4, sajaukti burti $m$ un $w$-citos avotos atrodams vien̄igi EE2 variants mūž̄̆gs.

\section{Sintaktiskās izmaiņas}

Izmaiņas EE2 teikuma sintaktiskajā struktūrā vērojamas 18 (11 evangêēliju un 7 epistulu) perikopēs. Tās EE2 var būt saistìtas ar vārdu secības maiņu (5.3.), prepozīicijām un ar tām saistīto locìjumu izmaiņām (5.2.) vai arī ar citām izmaiņām teikuma uzbūvē (5.1.).

5.1. 20. gs. pastāvēja uzskats (sk. Augstkalns 1934: 13; Ozols 1965:91), ka EE sintakse ir aplama un kḷūdaina, jo EE esot burtisks tulkojums no Lutera Bībeles, līdz ar to pārtulkotas arī vācu valodas sintaktiskās konstrukcijas. Tomēr jau gadsimta beigās šos asos apgalvojumus kritizējis P. Vanags (1996), lai gan atzinis, ka attiecība starp EE latviešu valodas arhaiskajām konstrukcijām un tām, kuras seko lejasvācu tekstam, ir nesamērojama. Pēc EE1 un EE2 salīdzināšanas tam var tikai piekrist un piebilst, ka bieži maiņas otrajā izdevumā neliekas nejaušas un lielākoties var tikt uzskatītas par apzinātu vācisku konstrukciju nomaiņu pret latviskākām. Piemēram, tas vērojams pi e d e rības teikumos. Lai gan EE1 visai konsekventi bija ievērota latviešu valodas piederības konstrukcija (sk. Vanags 1996: 71), dažviet vēl saskatāmas vācu valodas pēdas un log̣iskais subjekts lietots nevis datīvā, bet nominatīivā. Tas vietām pamanìts un EE2 labots: Aefto tho buus yums / Bynnath ka neewens Moutczenex ieb neeffkyftz / ieb neegoußyx (katetrs tur gir wens Elkedewe $\underline{\text { kalps) }}$ neewene dallibe gir / exkan tho walltybe Chrifti vnde Dewe $\rightarrow$ Ka neewenam Moutczeneka yeb neeffkyfta / yeb neegoußyga (Katters gir wena

${ }^{38} \mathrm{LB}-[.$.$] du sollst nicht falsch Zeugnis geben [..]; LVM1 - [..] Töw nhe buhß nhe patteefu leezibu$ doht $[.$.$] .$

${ }^{39} \mathrm{LB}-[.$.$] Sie truncken aber von dem geistlichen Fels [..]; LVM1 - [..] bett tee dfehre no to gharrigu$ Ackmini [..]. 
Elkedewe kalps) neewene dallibe gir (Ef 5:5 $)^{40}$. Citētajā piemērā redzama vēl viena sintaktiskā maiņa iekavās esošajā vārdkopā - nenoteiktā artikula vietā lietotais skaița vārds viens EE2 saskaņots ar atkarīgo komponentu (Elkedewe), nevis ar neatkarīgo (kalps), kā tas ir EE1.

Tas pats jāsaka par nākamo piemēru, kurā log̣iska subjekta locìjums ir precizēts: vnde winge Köninge walftibe nhe buus gals $\rightarrow$ vnd winga Koninge Walftibey nhe buus gals (Lk 1:33) ${ }^{41}$. Šo maiņu, resp. precizējumu, ir pamanījis jau A. Augstkalns (1933:49-50), kas teicis, ka datīva apzīmēšana ar $e$ šai vietā laikam radusies, rakstìtājam nesadzirdot divskani, tomēr, ja EE1 lietotā forma walftibe apzīmē nominatīvu, tas visdrīzāk būs radies attiecīgas vācu valodas konstrukcijas ietekmē.

Datīva un nominatīva maiņa vietniekvārdā vērojama vēl dažos piemēros: ka yums ftaigaath buufe $\rightarrow$ Ka yuus ftaigaath buufe (1Tes 4:1) un pretēji Mhers / taps yums exkan yuufe kleepe dhotz. Aefto / ar to Mhere / ar kattre yuus Jfmherifeeth / taps yums atkal emherydtcz $\rightarrow$ aifto / ar to Mhere / ar kattre yums Jfmherifeeth / taps yums atkal emherydtcz (Lk 6:38) ${ }^{42}$. Tomēr te abos teikumos tā visdrīzāk ir EE2 kḷ̂̄uda (varbūt hiperkorekcija), jo locījuma maiņa tādā sintaktiskajā pozīcijā nav pamatota. Šai sakarā jāmin vēl viens interesants piemērs - pallydtcze muns $\rightarrow$ pallidtcze muus (Mt 8:25), kas ir iespējamas kḷūdas vietā izdarìta cita iespējama kḷūda, jo gan EE1, gan EE2 verbs palìdzēt visos padsmit gadījumos EE pārvalda objektu datīvā. ${ }^{43}$

Piederības izteikšana mainìta vēl citā vietā: Joutaye tims Jefus vndeßatcy / ko domaath yuus no Chrifto ? ka Dhels gir tas ? $\rightarrow$ Joutaye thims JEfus vnde ßatcy / ko domaath yuus no Chrifto? kam Dhels gir tas? (Mt 22:41-42) $)^{44}$. EE1 piederība izteikta g̊enitīvā, bet EE2 - datīvā, tomēr šai gadīịumā nevar pilnīgi

${ }^{40}$ LBž - Wente dat schöle gy weten / dat nen Horenyeger / edder vnreyne / edder Giriger (de dar ys ein Affgöde Dener) Erue hefft in dem Kyke Christi unde Gades; LB - Denn das solt jr wissen / das kein Hurer oder Vnreiner oder Geitziger (welcher ist ein Götzendiener) Erbe hat an dem reich Christi vnd Gottes; LVM1 - Aifto to buhß jums finnaht / ka nhe weenam Mauzeneekam / jeb nhefkieftam / jeb nhegaufcham (katters gir weens ällka=deewa Kallps) nheneekada dalla gir py to Wallfibu CHrifti vnd Deewa.

${ }^{41}$ LBž - [..] vnde synes Köninckrykes wert nen ende syn; LB - [..] vnd seines Königreichs wird kein ende sein; LVM1 - [..] vnd tha Koninja=Wallftiba nhe mittehf'sees.

${ }^{42}$ LBž - [..] Wente mit der Mathe / dar gy mede methen [..]; LB - [..] Denn eben mit dem Mas / da jr mit messet [..]; LVM1 - [..] Aifto ar to Mähru / ar kattru juhß ißmehrohfśeeta [..].

43 Jāpiemin interesanta sakritība - Tartu Universitātes bibliotēkas 1587. g. EE eksemplārā ar roku ierakstīta dziesma Wens stippers pils gir muse Dews (par to Augstkalns 1935:28-33), kurā viscaur mums vietā tiek rakstīts muns, un vienā vietā ir pat pie tā paša verba - tas pallidtze muns. Gan J. Endzelīns, gan A. Augstkalns norāda, ka tāda disimilēta forma esot sastopama izloksnēs, bet līdztekus izsaka arī šaubas, vai norakstītājs pareizi atšífrējis (Augstkalns 1935: 32). Laikam arī EE1 šì vienreiz lietotā forma ir norakstītāja vai drīzāk burtliča atšifrēšanas kḷūda.

${ }^{44}$ LBž - [..] fragede se Jhesus vnde sprack: Wo düncket yuw by Christo: Wens Söne ys he? [..]; LB[..] Fraget sie Jhesus / vnd sprach / Wie dünckt euch vmb Christo? Wes son ist er? [..]; LVM1 - [..] jautaya tohß JEfus/ vnd śatziya: Ko Jkeetaht juhß no CHrifto? Ka Dähls gir tas? [..]. 
izslēgt arī nejauš̄ibu, jo vārdi atšķiras tikai ar vienu beigu burtu, lai gan tas ir maz ticams, jo burts pielikts, nevis atmests.

Ar locìjumu izvēli saistītu maiņu vai precizējumu EE2 ir vairāk, piem., $k a d$ es man patthe godhete $\rightarrow$ kad es manni patthi godhete (Jñ 8:54); Juus dheweet man Meyfter $\rightarrow$ Juus dhewet manni Meyfter (Jņ 13:13). Te ir grūti noteikt, ko ìsti EE1 apzīmē vārds man - ja datīvu, tad tā ir maiņa, bet ja akuzatīvu - precizējums. N̦emot vērā P. Vanaga (1996: 75) pamanìtu īpatnību, ka lejasvācu valodā vsk./dsk. dat. un ak. netiek šķirti, jādomā, ka tas ir datīvs, kas EE1 radies tulkojumavota iespaidā.

Divreiz locijumu maiņas notikušas vārdu savienojumos: wens Spittals wyrs naetce $\rightarrow$ wens Spittalu wyrs naetce (Mt 8:2 $)^{45}$ un thäs Debeffes Jtip=prums $\rightarrow$ thäs Debbeßu ftipprums (2Pēt 3:10). Šksiet, abos piemēros pāriets uz vīr. dz. dsk. ğenitīvu. Lai gan vārds debesis apzīmētājā EE sastopams itin bieži, šādā formā, proti rakstībā, fiksēts vienīgo reizi.

Vēl pie sintakstiskajām izmainaām jāmin EE1 pleonastiskas konstrukcijas lietojums ar papildu pronomenu blakus atgriezeniskam verbam, kas EE2 at-

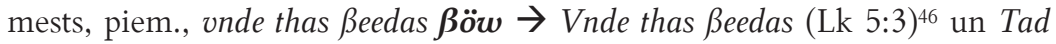
greßes $\boldsymbol{\beta} \ddot{w} \boldsymbol{w}$ Jefus apkarth $\rightarrow$ Thad greßes JEfus apkaärth (Mt 9:22) $)^{47}$. Kaut arī tas nav darīts konsekventi, jo atmests tikai šajās divās vietās, bet pārējās vairāk nekā simt vietās ir atstāts.

5.2. Izmaiņas redzamas arī p r e p o zīc cijās un to pārvaldìtajos locìjumos. Vienreiz pēc vācu valodas parauga lietota prievārda konstrukcija EE2 nomainìta pret illatìva formu: no tims muerronims / py tho treffche dene $\rightarrow$ nho thims mürronims / than treffchan denan (Lk 24:46). Trīs reizes EE2 precizēts vai mainīts prievārdu saistījums ar noteiktām locījuma formām: pa labbe vnd pa kreyfe roke $\rightarrow$ pa labbey vnd pa kreyfey roke (2Kor 6:4); aefto no tho manne thas to yems $\rightarrow$ aifto no tha manne thas to yems (Jn 16:14); ftipprims tapt czour Bouwe Garre / py tho efchige Czilwheke $\rightarrow$ ftipprims tapt czour ßouwe Garre / py tha efchige Czilwheke (Ef 3:16); grib es to py yums fuutyth $\rightarrow$ grib es tho py yuus fuutyth (J̣n 16:7). Te konsekvence nav vērojama, jo ar citētajiem prievārdiem vienskaitlī EE vārdi pārmaiņus lietoti gan akuzatīvā, gan g̊enitīvā.

${ }^{45}$ LBž - Vnde sae / ein Vthsettisch man quam vnde bedede en an [..]; LB - Vnd sihe ein Aussetziger kam / vnd betet jn an [..]; LVM1 - Vnd raugi / weens Spittaliex Wiers nahze / vnd peeluhdfe to $[.$.$] .$

${ }^{46}$ LBž - [..] Vnde he settede sick [..]; LB - [..] Vnd er satzte sich [..]; LVM1 - [..] ond tas pafśedeyah $\beta[.$.$] .$

${ }^{47}$ LBž - Do wende sick Jhesus vmme [..]; LB - Da wendet sich Jhesus vmb [..]; LVM1 - Tad attgrefeh $\beta$ JEfus apkahrt [..]. 
5.3. Salīdzinot EE izdevumus, atklājas vārdu secības maiņa, kas notikusi četros gadījumos, piem., EE1 apzīmētājs seko aiz apzīmējamā vārda, savukārt EE2 apzīmētājs pārcelts pirms tā, kā arī ir ierasts latviešu valodā: JEfu tu Dhels Dauide $\rightarrow$ JEfu tu Dauids Dhels (Lk 18:38) ${ }^{48}$. Vienreiz apzīmètājs, kas EE1 citvalodu ietekmē teikumā novietots tālu no apzīmētāja, uztveres atvieglošanai pietuvināts: Beth mhes / mylige Brale effem Jfaacs / peetcz to peßatcy/chenne Bherne $\rightarrow$ effem Ifaacs / Bherne Peetcz tho peßatcyfchenne (Gal 4:28) ${ }^{49}$. Arī trešajā piemērā vārdu secības maiņa izslēdz iespējamo EE1 pārpratumu: aefto ka tu nhe touwe kaye py wene Ackmenne nodouffe $\rightarrow$ Kha tu teuwe kaye nhe py wene Ackmenne nodouffe (Mt 4:6) ${ }^{50}$. Ceturtais piemērs varējis rasties, pārrakstot tekstu vai arī to liekot-gaye tas tims czour to Szirde / vnd ßackode tös Sobes $\rightarrow$ gaye tims thas czour tho Szirde / vnde ßacköde tös Sobus (Apd 7:54)51. Kad vārdi ir tik līdzīgi, gan pārrakstītājs, gan burtlicis viegli tos varējuši samainīt vietām pat nepamanot.

\section{Strukturālās izmaiņas}

Kopējā EE2 krājuma struktūra no EE1 neatškiras - jauni fragmenti nav pielikti un jau esošie nav mainīti vietām, saīsināti vai papildināti. Līdz ar to par strukturālajām izmaiņām tiek uzskatītas tādas, kas radušās panta vai teikuma robežās, nevis perikopju krājuma struktūrā. Tādu EE2 ir daudz - 42 perikopēs, tomēr pielikumu (6.1.) ir piecreiz mazāk nekā izlaidumu (6.2.) (sk. 1. diagrammā attiecīgi 7. un 8. tipu).

\subsection{Pielikumi}

Salīdzinot EE1 un EE2, pielikumi atrodami 7 perikopēs - 3 evaņgéeliju un 4 epistulu izvilkumos (sk. 1. diagrammā 8. tipu). Trīs no tiem ir ekvivalenti visiem iespējamiem tulkojuma avotiem un izskatās drīzāk kā EE1 nejaušu izlaidumu labojumi: Dene vnde Nackte es exkan tho czillumme täs Jures buewis $\rightarrow$

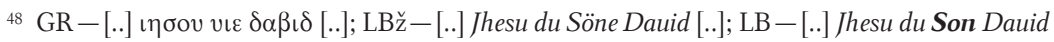
[..]; LVM1 - [..] JESV tu Dawida dähls [..].

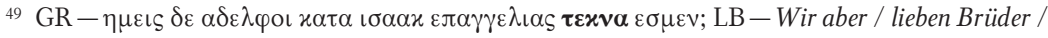
sind Jsaac nach / der verheissunge Kinder; LVM1 - Bett mehs / myḷi Brahḷi / äfśam Jfaaca / pehtz to śolifchanu / Bährni.

${ }^{50}$ LBž - vp dat du dynen Vöth / nicht an eynen Steen stötest; LB - Auff das du deinen fuss nicht an einen stein stössest; LVM1 - ka tu śawu Kahyu py nhekahdu Ackmini daufi.

${ }^{51}$ LBž - ginck ydt en dorch dat herre / vnde beten de teenen auer en thosamende?; LB - Giengs jnen durchs hertz / vnd bissen die zeene zusamen vber jn; LVM1 - ghaya taß teems czaur śirrdi / vnd śackohde tohß Sohbus par to; VLH - gahja tas teem zaur śirdi / in sakohde tohs Sohbus pahr winnnu. 
Dene vnde Nackte efme es exkan tho czillumme täs Jures buiwis (2Kor 11:25) ${ }^{52}$; Bedeye wens py tho czelle $\rightarrow$ Bedeye wens acklis py tho czelle (Lk 18:35) $)^{53}$; Ludtczeeth / thad yuus dabbufeeth / yuufe lyxmibe puelnige gir $\rightarrow$ yuus dabbufeth / Ka yuufe lyxmibe pülnige gir (J̣n 16:24) ${ }^{54}$. Tomēr pārējiem pielikumiem atbilsmju citos avotos nav, piem., tad gir the arridtczan Dewe walftibes Manteneke / Czour Chriftum $\rightarrow$ Czour IEfum Chriftum (Gal 4:7) ${ }^{55}$. Lai gan īstais pielikšanas iemesls nav skaidrs, tulkojumos personvārdu Jēzus mēdz apzināti pielikt blakus esošajam Kristus neatkarīgi no tā, vai tas ir avottekstā. Taču nākamos pielikumus par apzinātiem grūti saukt, jo daži ir acīmredzama jauna EE2 korektūras kḹūdaBeth par thöw vfedth tas kunx $\rightarrow$ Beth pär thöw vfedth tas ras Kunx (Jes 60:2) un pawheeley tas Kunx paardoth / ßöw / vnd Bouwe Sewe $\rightarrow$ pawheley thas Kunx paardoth / ßöw / vnd vnde ßouwe Sewe (Mt 18:25). Abos gadijumos redzams iepriekšèjās leksēmas atkārtojums - ras ir līdzịgs vārdam tas, bet un atkārtots, pārcel̦ot teikumu uz nākamo rindiņu (pirmais vnd ir pēdējais rindas vārds, otrs vnde - pirmais). Iespējams, vēl viens š̄s grupas piemērs - Kattrims thas $\beta$ öw peetcz ßouwe czefchenne czywis paradyes by / czour daffchade paradifchenne $\rightarrow$ czywis paradies by tho / czour daffchade pa=radiffchenne / (Apd 1:3) $)^{56}-\mathrm{j} \overline{\mathrm{a}}-$ uzskata par EE2 kḷūdu, jo papildinātāja lietošana pantā nav pamatota un pat rada pārpratumu.

\subsection{Izlaidumi}

Izlaidumi EE2 vērojami pat 35 perikopēs - 21 evaņgéliju un 14 epistulu izvilkumos. Tie pēc struktūras iedalāmi divās grupās: dažu (6.2.1.) vai viena (6.2.2.) vārda izlaidumos, kas veido acīmredzamu vairākumu.

6.2.1. Gandrīz visi vairāku blakus esošu vārdu izlaidumi tiek uzskatīti par t. s. parablepsi, kas radusies kā burtliča vai pārrakstītāja lasīšanas kḷ̂ùdas, kad līdzīga teikuma daḷa, liekot vai pārrakstot tekstu, izlaista. Salīdzinot EE1 ar EE2, vienā pantā fiksēti pat divi tādi izlaidumi (a), tomēr lielākoties pantā ir pa vienam (b):

${ }^{52}$ LBž - [..] Dach vnde nacht hebbe yck thogebracht / ynn der düpede des Meers; LB - [..] Tag vnd nacht hab ich zubracht in der tieffe des meers; LVM1 - [... Deenu vnd nackti äßmu es Juhŗa dfillumà biyis.

${ }^{53} \mathrm{LBž}-$ [..] satt ein Blinde am wege [..]; LB - [..] sass ein Blinder am wege [..]; LVM1 - [..] śehdeya weens Acklis Czellmaly [..].

${ }^{54} \mathrm{LB}$-Biddet / so werde gy entfangen / dat yuwe fröuwde vullenkamen sy; LB - Bittet / so werdet jr nemen / das ewre freude volkomen sey; LVM1 - Luhdfeeta / tad juhß jemfśeeta / ka juhfśa liexmiba pillniga warr buht.

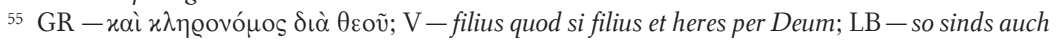
Erben Gottes / durch Christum.

${ }^{56}$ LBž - [..] lëuendich bewyset hadde [..]; LB - [..] lebendig erzeiget hatte [..]; LVM1 - [..] dfiews paradiyees by [..]. 
a) Tha czerre wueffe lethe / Ta pe czefche wueffe lethe. Ta myleftibe nhe tope pekuffuffe / ka tomher ta prefche fluddenafchenne nomitteeffes vnde täs Wallodes nomitteeffes $\rightarrow$ Tha czerre wuffe [..] lethe. Ta myleftibe nhe thope pekuffuffe / Ka tomher tha prefche fluddenafchenne [..] nomitteeffes (1Kor 13:8);

b) tappe lydtcz ka wens citcz Czilwhex / vnde no prate kha wens $\underline{\text { Czilwhex }}$ attraftz $\rightarrow$ tappe lydtcz ka wens [..] Czilwhex attraftz (Fil 2:7-8); vnd mhes redczeyam wynge godybe / wene godybe / kha tha wene peczimpte $\rightarrow$ vnde mhes redtczeyam winge godibe / [..] Kha tha wene peczimpte (Jn 1:14); es Backe thöw / czelles auxkam. Vnde tas Muerronis czeelhes auxkam $\rightarrow$ es ßacke thöw / czelles [..] auxkam (Lk 7:15); Enaydeneke apkärth thöw / vnd touwe Beerne ar thöw / wene ratte pille apkärth thöw Bittys $\rightarrow$ Enaydeneke apkärth thöw [..] Bittys (Lk 19:43); ka the to nhe redtcze / ieb the tho yow redtcz vnd nhe Bapprooth / ieb the tho yow czirde $\rightarrow$ Ka the tho nhe redtcze / [..] yeb te to yow czirde (Lk 8:10).

EE2 ir arī daži t. s. homoioteleuton izlaidumi (kad sakrīt tikai vārda beigas), piem., warrens nho darbims vnde wärdims prexkan $\rightarrow$ warrens no darbims [..] prexkan (Lk 24:19). Par tādu jāuzskata arī beth exkan thoßalde mykle $\underline{\text { täs }}$ tyribes $\rightarrow$ Beth exkan [..] täs tyribes (1Kor 5:8), lai gan pasvittrotie vietniekvārdi sakrīt daḹeji.

Tikai vienu no daudzajiem vairāku vārdu izlaidumiem EE2 var pielīdzināt apzinātai izmainai - Nhe by tham tad yums to doudtcze wayrack darrith ? $\rightarrow$ Nhe by [..] yums to doudtcze wairack darryth ? (Mt 6:30) -, tomēr arī tajā nav pilnībā izslēgta kḷūdas iespēja, jo citvalodu avotos un vēlākajos latviešu perikopju krājumos tāds papildinātāja izlaidums neparādās ${ }^{57}$.

6.2.2. Veselās 27 perikopēs EE2 fiksēti viena vārda izlaidumi. To izcelsme dažādāka nekā iepriekš aplūkotajās grupas, jo ne visus var uzskatīt par iespējamām kḹūām. Iedalot pēc vārdšķirām, var redzēt, ka tie tomēr lielākoties ir nelokāmi palīgvārdi vai artikula funkcijā lietots vietniekvārds tas, tā. No sintakses viedokḷa tie bieži vien ir teikuma palīglocekḷi.

6.2.2.1. Visbiežāk - 10 perikopēs - EE2 izlaists vi et n i e kvārds, kas EE1 ticis lietots. No tām septinas reizes tas, tāa, kas trīsreiz EE1 lietots vācu artikula vietā (a), divreiz ir salikta teikuma komponenta teikuma priekšmets (b), bet vienreiz papildinātājs (c) un vienreiz ir EE1 kḹūas atmešana (d):

a) gaye tas tims czour to Szirde / vnd ßackode tös Sobes $\rightarrow$ gaye tims thas czour tho Szirde / vnde ßacköde [..] Sobus (Apd 7:54) ${ }^{58}$; vnd prexkan tims

${ }^{57}$ LBž - [..] Scholde he yuw dat nicht vële mehr don? [..]; LB - [..] Solt er das nicht viel mehr euch thun [..]; LVM1 - [..] negg by tad tam to jums wehl wairahk darriet? [..].

${ }^{58} \mathrm{LBž}-[.$.$] ginck y d t$ en dorch dat herre / vnde beten de teenen auer en thosamende?; LB - [..] Giengs jnen durchs hertz / vnd bissen die zeene zusamen vber jn; LVM1 - [..] ghaya taß teems czaur śirrdi / vnd śackohde toh $\beta$ Sohbus par to; VLH - [..] gahja tas teem zaur śirdi / in sakohde tohs Sohbus pahr winnnu. 
Szunnims mheftha $\rightarrow$ Vnde prexkan [..] Szunnims mheftha (Mt 15:26) ${ }^{59}$; vnde kha ta Sepe täs Mafgatayes $\rightarrow$ vnde ka [..] Sepe thäs Mafgatayes (Mal 3:2) $)^{60}$;

b) Kad to te loudis redtczey / Jßabrinoyas the ßöw / vnde teytcze $\rightarrow$ Jfzbrynoyas [..] fzöw / Vnde teytcze (Mt 9:8) ${ }^{61} ;$ VNde kad thas atkal Jsgaya / no tims Eßyms Tyri vnde Sydon / nätce thas py to Galileifche Juure $\rightarrow$ nätcze [..] py tho Galilei che Juure (Mk 7:31) ${ }^{62}$;

c) Tad paßluddenaye the tham / Jefus no Nazareth edth tur fetczen $\rightarrow$ Tad paßfluddenaye te [..] JEfus no Nazareth edth tur czetczen (Lk 18:37);63

d) If=gaye aran to tho Bafnice $\rightarrow$ Jfgaye aran [..] tho Bafnice (Jn 8:59).

Meklējot a-c dalāàs citēto izmainu cēloni un salīdzinot piemērus ar to atbilsmēm citvalodu avotos (sk. vērēs), var redzēt, ka EE1 lietotajam vietniekvārdam tas, $t a \overline{~ v i e n m e ̄ r ~ i r ~ a t b i l s m e ~ L u t e r a ~ B i ̄ b e l e ̄, ~ t a ̄ p e ̄ c ~ t o ~ a t m e s ̌ a n u ~ E E 2 ~ n e v a r ~}$ skaidrot ar iespējamu tulkojuma vai redigீējuma avota ietekmi. Turklāt piecas reizes no sešām vietniekvārds saglābājies arī G. Manceḷa perikopju krājumā. Škiet, šis EE2 izmaiņas ir apzinātas, jo, piem., pat tad, kad atmests teikuma priekšmets (b), tas neizskatās pēc nejaušas izlaišanas - pirmajā salikta teikuma daḷā teikuma priekšmets skaidri izteikts un tā atkārtošana nav nepieciešama.

Trīs reizes EE2 atmesti arī citi vietniekvārdi, kas teikumā veic dažādas sintaksiskās funkcijas: Jefus ßatcy vs tho / peetcz to / ka tu man redtczeys effe Thoma thad titcztu $\rightarrow$ ka tu [..] redtczeys effe Thoma tad titcztu (Jn 20:29) ${ }^{64}$; Aefto kas ßöw pattim auxtenayas / tam buus Jemmotam tapt./ Vnde kas ßöw pattim Semmoyas $\rightarrow$ Aifto kas fzöw pattim auxtenayas / Tham buus Semmotam tapt. / Vnd kas fzöw [..] Jemmoyas / tham buus auxtenatam tapt (Lk 14:11)65;

${ }_{59} \mathrm{LBž}-[.$.$] vnde werpe ydt vor de Hunde; \mathrm{LB}-[.$.$] vnd werff es fur die Hunde; LVM1 - [..] vnd$ preekfch śunneems meft; VLH - [..] in śunnneems preekścha mejt.

${ }^{60}$ LBž - [..] vnde alse de Sepe der Wesscher; LB - [..] vnd wie die Seiffe der Wesscher; LVM1 - [..] ka tahs Seepes tahß Mafghatayas.

${ }^{61}$ LBž - Do dat Volck dat sach / vorwunderde ydt sick [..]; LB - Da das Volck das sahe / verwundert es sich [..]; LVM1 - Kad tee Laudis to redfeya / brynoyahß tee [..].

${ }^{62}$ LBž - Vnde do he wedder vthgynck van den Grentzen Tyri vnde Sidon/ quam he an dat Galileische Meer [..]; LB - VND da er wider ausgieng von den grentzen Tyri und Sidon / kam er an das Galileische meer [..]; LVM1 - KAd LEJus atkal ißghaya no teems Efcheems Tyri vnd Sydon I nahze tas py to Galileero Juhri [..].

${ }^{63} \mathrm{~V}$-Dixerunt autem ei quod Jesus Nazarenus transiret; LBž - Do vorkündigen se ew / Jhesus van Nazareth gynge dar vorauer; LB - Da verkündigeten sie $\mathbf{j m}$ / Jhesus von Nazareth gienge fur vber; LVM1 - Tad ftahftiya tee tam JEfus no Nazareth eijohtz czetczen.

${ }^{64}$ LBž - Jhesus spreckt tho em. Dewile dat du my geseen heffft Thoma / so gelöuestu [...]; LB Spricht Jhesus zu jm / Dieweil du mich gesehen hast Thoma / so gleubestu [..]; LVM1 - JEfus śatziya vs to: Tapehtz / ka tu mann redfeyis efśi Thoma / tad titzi tu [..].

${ }^{65}$ LBž - Wente wol sick süluest vorhöget / de schal vornedderr werden. Vnde wol sick süluest vornedderr / de schal vorhöget werden; LB - Denn wer sich selbs erhöhet / der sol ernidriget werden / Vnd wer sich selbs ernidriget / der sol erhöhet werden; LVM1 - Aifto kas śöw patz auxtenayahß / tam buhß fämmotam tapt / vnd kas śöw patz fämmoyah $\beta$ / tam buhß auxtenatam tapt. 
wedde vs to auxke / vnde if mettet yuufes tykles $\rightarrow$ wedde tho auxke / vnde $y$ fmettet [..] tyckles (Lk 5:4) ${ }^{66}$. Visos gadījumos EE1 lietotam un EE2 atmestam vietniekvārdam ir atrodams ekvivalents Lutera Bībelē.

6.2.2.2. Sešas reizes EE2 atmests saiklis - trīsreiz sakārtojuma saiklis un: no to Namme Dauid / vnde ta Jumprouwe dheweye Maria $\rightarrow$ no to Namme Dauid / [..] tha Jumprouwe dheweye Maria (Lk 1:27)67; Parther vnde Meder / vnd Elamiter $\rightarrow$ Parther vnde Meder / [..] Elamiter (Apd 2:9) ${ }^{68}$; citte apmhedidamme vnd ßatcy $\rightarrow$ czitte apmhedidamme [..] Batcy (Apd 2:13) ${ }^{69}$; divreiz pakārtojuma saiklis ka: kad the czeeruffche tappuffche gir / $k a$ tad to planako $\rightarrow$ kad the Peczeeruffche tappuffche gir / [..] tad tho planako (Jn 2:10)70; tekams ka thas naetcys $\rightarrow$ tekams tas nätcys (1Kor 11:26) ${ }^{71}$, bet vienreiz arī aizto: aefto ka tu nhe touwe kaye py wene Ackmenne nodouffe $\rightarrow$ [..] Kha tu teuwe kaye nhe py wene Ackmenne nodouffe (Mt 4:6) ${ }^{72}$. Vairumu no šiem piemēriem var uzskatīt par labojumiem, jo EE2 izmaiņas izslēdz pārpratumus (sal. Jņ 2:10) vai burtisko tulkojumu no teksta vācu valodā (Apd 2:13). Par to, ka Mt 4:6 atmešana nav nejauša, liecina ar lielo burtu lietots saiklis $k a$, kas iezīmē salikta teikuma daļas sākumu.

6.2.2.3. Trīs reizes EE2 izlaisti pri evārdi. Vienreiz tam nav pamatojuma, jo izlaišana piel̦auj pārpratumu - wedde vs to auxke / vnde if mettet yuufes tykles $\rightarrow$ wedde tho auxke / vnde yfmettet tyckles (Lk 5:4), tāpēc tā visdrīzāk jāuzskata par neapzinātu maiņu, lai gan otrs izlaistais vārds pantā, par kuru jau rakstīts, tādu pārpratumu neveido. Iespējams, ka arī šì izlaišana - katters tur nake / ar Vdenne vnde Af=Senne / Jefus Chriftus / nhe ar Vdenne wene / beth ar Vdenne vnd Affenne $\rightarrow$ Nhe [..] Vdenne wene / Beth ar Vdenne vnde Affenne (1Jn 5:6) - ir drukas kḷūda. Tomēr nākamajā piemērā prievārds uz, škịiet, izlaists, labojot burtisko tulkojumu no vācu valodas - beth gaydite vs to peßatcifchenne

${ }^{66}$ LBž - Vnde alse he hadde vpgehöret tho redende / sprack he tho Simon: Vare vp de högede / vnde werpet yuwe Nette vth / dat ghy einan toch don; LB - VND als er hatte auffgehört zu reden / sprach er zu Simon / Fare auff die höhe / vnd werffet ewre Netze aus / das jr einen zug thut; LVM1 - Vnd kad tas beidfe runnaht / śatziya tas vs Simoni / dohdees vs auxtu / vnd ißmetteeta juh/śus Tieklus / ka juhß weenu Lohmu wällkaht.

${ }^{67}$ LBž - [..] van dem Huse Dauid / vnde de Jungfrouwe hethe Maria; LB - [..] vom hause Dauid / vnd die Jungfraw hies Maria; LVM1 - [..] no to Czilltu Dawida / vnd ta Jumprawa dehwehya Maria.

${ }^{68}$ LBž - Parther / vnde Meder / vnde Elamiter [..]; LB - Parther vnd Meder / vnd Elamiter / [..]; LVM1 - Partherii / vnd Meedeṛi / vnd Elamiteṛi [..].

${ }^{69}$ LBž -De anderen auerst hadden erspoth daruth / vnde spreken [...]; LB - Die andern aber hattens jren spot / vnd sprachen [..]; LVM1 - Bett czitti apmehdidami śatziya [..].

${ }^{70}$ LBž - [..] vnnde wenn se druncken worden synt / alse denn den ryngern [..]; LB - [..] vnd wenn sie truncken worden sind / als denn den geringern [...] LVM1 - [..] ond kad tee peedfärufchi gir / tad to plahnaku [..].

${ }^{71}$ LBž - [..] beth dat he kümpt [..]; LB - bis das er kompt [..]; LVM1 - teekams tas nahk [..].

72 LBž - [..] vp dat du dynen Vöth / nicht an eynen Steen stötest; LB - [..] Auff das du deinen fuss nicht an einen stein stössest; LVM1 - [..] ka tu śawu Kahyu py nhekahdu Ackmini daufi. 
tha Theewe $\rightarrow$ beth gaidite to peßatci chenne tha Thewe (Apd 1:4)73. Interesanti, ka, lai gan EE2 šis pārvaldījums mainīts, visos perikopju krājumos pēc tā, arī Glika Bībelē, verbs lietots ar prievārdu (sk. vērē).

6.2.2.4. Četras reizes atmests verbs, proti verba būt forma, kas teikumā bieži vien ir izteicēja saitiņa: pagane loudis buewuffche effeth / vnd effeth nogayfche py tems $\rightarrow$ pagane loudis büwuffche effeth / vnd [..] nogayfche py tems (1Kor 12:2); touwa meßige drougaina / gir arridtczan apgrutenata $\rightarrow$ touwa meßige drougaina / [..] arridtczan apgrutenata (Lk 1:36 ${ }^{74}$; katters tur warens gir $\rightarrow$ katters tur warens [..] (Lk 1:49) ${ }^{75}$. Vienreiz fiksēts arī šāds izlaidums Tades wärdes effeme es vs yums treßeys / tickilge ka es py yums buewis efme $\rightarrow$ tickilge ka es py yums [..] effme (Jñ 14:25) ${ }^{76}$. Lai gan formāli šo piemēru varētu uzskatīt par izmainu morfolog̣ijā, jo, šādi atmetot vienu saliktā laika komponentu, divdabi bijis, liekas, ka tas ir labojums uz vienkāršo tagadni. Tomēr vienkāršās tagadnes lietošanu nepamato neviens no avotiem, kā arī iepriekšejjā saliktā teikuma daļa, tāpēc tas uzskatīts par izlaišanu, nevis nomaiņu.

6.2.2.5. Pa vienai reizei atmesti sk a it l̦ a vārds: no fchims trims tas Tuwakays $\rightarrow$ no fchims [..] thas Tuwackays (Lk 10:36) ${ }^{77}$; a p stā k ḷ a vārds: arridtczan $\int$ thawe atkal raxtytz $\rightarrow$ Arridtczan fthawe [..] raxtytz (Mt 4:7 $)^{78}$ un li et vā rds: vnde ßode ar wueffe prate $\rightarrow$ vnde ßode ar wüffe [..] (Tit 2:15) ${ }^{79}$. Arī šai gadījumā leksēmas izlaišana vērojama vienīgi EE2 - tā lietota gan Jaunajā Derībā sengrieķu valodā, gan Vulgātā, gan Lutera Bībelē un latviešu perikopju krājumos.

\section{Secinājumi}

7.1. EE1 un EE2 perikopju krājumi atšksiras. Izmainas fiksētas dažādos valodas līmeņos, tomēr tās šajā rokasgrāmatas dạiā nav tik ievērojamas, lai to

${ }^{73}$ LBž - [..] sunder wachteden $\boldsymbol{v p}$ de thosage des Vaders [..]; LB - [..] sondern warteten auff die Verheisung des Vaters [..]; LVM1 - [..] bett ghaidiet vs to śohlifchanu ta Tähwa [..]; VLH - [..] bet gaidiht us ta Tehwa śohliśchanu [..]; GB - [..] bet gaidiht us to Apśohliśchanu ta Tehwa [..].

${ }^{74}$ LBž - [..] dyne angebarne Fründinne / ys ock swanger [..]; LB - [..] deine gefreundete / ist auch schwanger [..]; LVM1 - [..] tawa Radda / gir arridfan apghrutenata [..].

75 LBž - [..] de dar mechtich ys [..]; LB - [..] der da Mechtig ist [..]; LVM1 - [..] katters Spehziex gir [..].

${ }^{76} \mathrm{LBž}-[.$.$] dewile dat yck by yuw gewest bin; LB - [..] weil ich bey euch gewesen bin; LVM1 - [..]$ teekams es py yums äßmu biyis.

${ }^{77}$ LBž - [..] dessen dren / de a Negeste [...]; LB - [... der vnter diesen dreien der Nehest [..]; LVM1[..] no fcheems trimm to Tuwaku [..].

${ }^{78}$ LBž - Do sprack Jhesus tho em: Wedderümme steyth ock geschrenen: Du schalt Godt dynen HEREN nicht vorsöken; LB - Da sprach Jhesus zu jm / Widerumb stehet auch geschrieben / Du solt Gott deinen HERRN nicht versuchen; LVM1 - Tad śatziya JEfus vs to : Arridfan ftahw attkall raxtietz / thöw nhe buhß Deewu tawu Kungu kahrdenaht.

79 LBž - Solckes rede / vnde vormane / vnde straffe mit gantzem ernste [..]; LB - Solches rede vnd ermane / vnd straffe mit gantzem ernst [..]; LVM1 - To śacki / vnd peemini / vnd śohdi no wifśas sirdts [..]. 
varētu uzskatìt par pilnīgi jaunu redakciju. Ir ļoti daudz izmaiņu, kuras nav iespējams kaut cik droši izskaidrot, un vairums no tām ir apšaubāmas, jo visdrīzāk uzskatāmas par neapzinātām maiņām, nevis īstiem labojumiem. Jāteic, ka lielākoties izmaiņas ir vienreizèjas un bieži citētajos piemēros vārdi atšķiras tikai ar vienu burtu, līdz ar to nejaušības iespēja pieaug.

Pēc 2. diagrammā un 1. tabulā sniegtajiem datiem var redzēt, ka izmaiņu tipi sadalījušies ļ̣oti nevienlīdzīgi. Visvairāk ir rakstības izmaiņu, kas ir vērojamas visās EE perikopēs, pēc tam ierindojas precizējumi un izlaidumi, bet pārējo tipu izmaiņu ir mazāk. Gandrīz visas izmaiņas biežāk veiktas evaņgêeeliju, nevis epistulu izvilkumos, iznememot leksiskās izmaiņas un izlaidumus. Tomēr jāteic, ka tieši šo tipu izmainas visbiežāk ir neapzinātas un uzskatāmas par drukas kḷūdām.

2. diagramma

Izmaiņu tipu sadalījums EE2 pēc to kopējā daudzuma

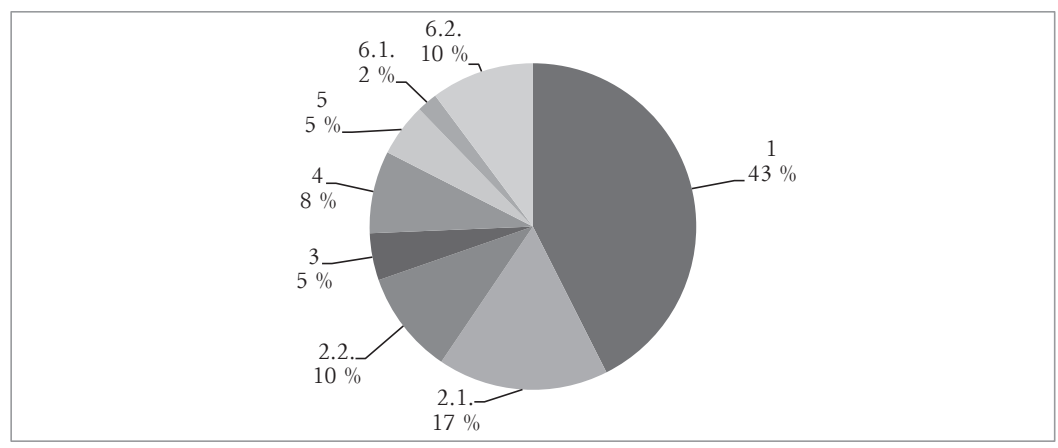

1. tabula

Izmaiņu tipu sadalījums EE2 pēc to atrašanās vietas

\begin{tabular}{|c|c|c|c|c|}
\hline \multicolumn{2}{|c|}{ Izmaingas } & $\begin{array}{l}\text { Evañgēliju } \\
\text { izvilkumi }\end{array}$ & $\begin{array}{l}\text { Epistulu } \\
\text { izvilkumi }\end{array}$ & $\begin{array}{c}\text { Kopā (izvilkumu } \\
\text { daudzums perikopju } \\
\text { krājumā / \%) }\end{array}$ \\
\hline \multicolumn{2}{|l|}{ 1. Rakstībā } & 73 & 73 & $146(100 \%)$ \\
\hline \multirow{2}{*}{ 2. Morfologijāā } & 2.1. Precizējumi & 34 & 24 & $58(39,72 \%)$ \\
\hline & 2.2. Citas izmaiņas & 22 & 13 & $35(23,97 \%)$ \\
\hline \multicolumn{2}{|c|}{ 3. Vārddarināšanā } & 8 & 8 & $16(10,96 \%)$ \\
\hline \multicolumn{2}{|c|}{ 4. Leksikā } & 13 & 15 & $28(19,17 \%)$ \\
\hline \multicolumn{2}{|l|}{ 5. Sintaksē } & 11 & 7 & $18(12,33 \%)$ \\
\hline \multirow{2}{*}{$\begin{array}{l}\text { 6. Perikopes } \\
\text { struktūrā }\end{array}$} & 6.1. Pielikumi & 3 & 4 & $7(4,79 \%)$ \\
\hline & 6.2. Izlaidumi & 21 & 14 & $35(23,97 \%)$ \\
\hline
\end{tabular}


7.1.1. Citas morfologiskās izmainas EE2 vērojamas 35 perikopēs. Vairumu veido darbības vārdu formu maiņas. Tās notikušas gan verba izteiksmē, gan laika kategorijā, bet lielākais klāsts piemēru ir saistīts ar dažādiem variantiem, kas izloksnēs ir fiksēti arī mūsdienās. Nomenu izmainas lielākoties veiktas, mainot tā dzimti virzienā vìr. $d z . \rightarrow$ siev. $d z$., bet ir arī dažas citas, kā lokāma piederības vietniekvārda maiņa uz nelokāmu vai illatīva apzīmēšana ar $-m$, nevis ar $-n$.

7.1.2. Vārddarināšanā ir vismazāk izmaiņu - 16 perikopēs. Te nedaudz vairāk piemēru ir verbiem, nevis nomeniem. Formāli skatoties, darbības vārdos veiktas gan prefiksālas, gan sufiksālas izmaiņas, bet dažos gadījumos grūti noliegt nejaušību un rakstības kḷūudu ietekmi. Viens no interesantākajiem piemēru klāstiem ir vārda dabūt jauktā paradigma, kas atpoguḷojas EE2 izmaiņās. Nomenu maiņas EE2 lielākoties ir sufiksālas, bet ir arī daži citi okazionāli gadījumi, kā by=fchenne $\rightarrow$ bya/chenne, tomēr, tos skaidrojot, grūti izslēgt nejaušības iespēju.

7.1.3. Leksikā ir samērā daudz izmaiņu -28 perikopēs -, tomēr arī iespējamo korektūras kḷūudu skaits šà tipa izmaiņās ir ievērojams. Tas ietekmē to, ka visbiežāk EE1 un EE2 attiecīgajā vietā atšķiras saiklis, kas īstenībā vienā no avotiem salikts nepareizi. Tā apgalvot ḷauj tikai viena burta atšksirība vārdos $($ kad $\rightarrow$ kas, kad $\rightarrow$ ka). Tomēr dažos gadījumos leksēmu nomaiņa ir neapšaubāma, tādu gadījumu visvairāk ir verbiem (czefth $\rightarrow$ buth) un nomeniem (nodzibe $\rightarrow$ Kailum).

7.1.4. Izmainas EE2 teikuma sintaktiskajā struktūrā vērojamas 18 perikopēs. Tās EE2 piecas reizes ir saistītas ar prepozīcijām un ar tām saistīto locījumu maiņām, četras - ar vārdu secības maiņu, bet pārējās ir citas dažādas izmaiņas teikuma uzbūvē. Gandrīz visas uzskatāmas par interferences kḷūuu labošanu, kad vāciskas konstrukcijas vai vārdu secība tikusi latviskota vai precizēta. Iespējamo neapzināto maiņu šajā tipā ir maz.

7.1.5. Strukturālās izmaiņas EE2 iedalītas divās grupās: pielikumos, kuru ir piecreiz mazāk, un izlaidumos. Četrās perikopēs no septin̄ām pielikumi ir pamatoti un uzskatāmi par EE1 izlaidumu labojumiem, tomēr trīs gadījumi ir no jauna EE2 pię̧autas kḷ̂ùdas. Izlaidumi, kas var būt gan viena, gan vairāku vārdu apmērā, EE2 vērojami veselās 35 perikopēs. Vairāku vārdu izlaidumi fiksēti 8 perikopēs, un gandrīz visi ir parablepses jeb lasīšanas kḷūdas, bet viena vārda izlaidumu izcelsme ir daudzveidīgāka, un to ir trīsreiz vairāk. Te arī lielākā daḷa uzskatāma par korektūras kḷ̂ùām, tomēr daḷa ir acìmredzami uzlabojumi. 
7.2. Izanalizējot EE1 un EE2 atšksirīibas, šo to var pateikt arī par EE2 sagatavošanas principiem. Pirmkārt, drukātam tekstam raksturīgo kḷūdu pārmantošana rāda, ka EE2 teksts salikts, izmantojot manuskriptu, kas radies no EE1 drukātā teksta, nevis izmantojot kādu nezināmu agrāku manuskriptu. Otrkārt, 1. diagrammā ir skaidri redzams, ka EE2 perikopju pirmajā pusē maiņu ir vairāk nekā otrajā, tas rāda, ka pirmās perikopes redig̣êtas vairāk nekā tālāk esošās. Treškārt, daži piemēri liecina, ka dạ̧a labojumu varēja būt ievietoti virs attiecīgā vārda vai tam blakus, jo saliktā forma ir grūti izskaidrojama (sk. Iņ 2:9, Jņ 8:49).

\section{Avoti}

\begin{tabular}{|c|c|}
\hline $\mathrm{EE} 1=$ & Euangelia vnd Episteln <...>. 1587. \\
\hline $\mathrm{EE} 2=$ & Euangelia vnd Episteln <...>. 1615. \\
\hline $\mathrm{GR}=$ & $\begin{array}{l}\text { Nestle-Aland [ed.], Novum Testamentum Graece et Latine, Stuttgart: Deutsche Bibel- } \\
\text { gesellschaft. 2005. }\end{array}$ \\
\hline $\mathrm{LB}=$ & Biblia: das ist: die gantze Heilige Schrifft deutsch, Wittemberg, 1545. \\
\hline $\mathrm{LBž}=$ & $\begin{array}{l}\text { Biblia. Dat ys: De gantze Hillige Schrifft / Vordüdeschet dorch Doct: Mart. Luth. Uth } \\
\text { der lesten Correctur mercklick vorbëtert unde mit grotem vlyte corrigeret, Gedrückt tho } \\
\text { Wittemberch dorch Hans Lufft, } 1569 \text {. }\end{array}$ \\
\hline LVM1 = & Mancelius, Georgius. Lettisch Vade mecum, 1631. \\
\hline $\mathrm{V}=$ & $\begin{array}{l}\text { Biblia Sacra Iuxta Vulgatam Versionem. Citēts no: BibleWorks7, red. - R. Weber, } \\
\text { B. Fischer, J. Gribomont, H. F. D. Sparks. }\end{array}$ \\
\hline
\end{tabular}

\section{Literatūra}

Apīnis, Aleksejs. 1977. Latviešu grāmatniecība: no pirmsākumiem lìdz 19. gs. beigām. Rīga: Liesma.

Apīnis, Aleksejs. 1991. Pirmā latviski Rīgā iespiestā grāmata kā literāra problēma. Dail literatūra latviešu grāmatniecībā. Rīga: Avots, 11-24.

Augstkalns, Alvils. 1930a. Piezìmes par veclatviešu rakstiem. Filologu biedrïbas raksti, 10, 97-112.

Augstkalns, Alvils. 1930b. Veclatviešu rakstu apskats. RLB ZK Rakstu krājums, 20, 92-137.

Augstkalns, Alvils. 1933. Mūsu vecie raksti. Filoloğijas materiāli. Profesoram J. Endzelīnam sešdesmitajā dzimšanas dienā veltīts rakstu krājums. Rīga: Ramave, 41-58.

Augstkalns, Alvils. 1934. Mūsu valoda, vingas vêsture un pètītāji. Rīgā: Valtera un Rapas akc. sab. izdevums.

Augstkalns, Alvils. 1935. Wens stippers pils gir muse Dews. Ceľ̦s, 1, 28-33.

Endzelīns, Jānis. 1951.

Latviešu valodas gramatika. Rīga: Latvijas Valsts izdevniecība.

Kazakènaite, Ernesta. 2017. Izmaiņas Georga Mancel̦a 1631. g. un 1644. g. Lettisch Vade mecum perikopiu dạ̦ā. Baltu filoloğija, 26 (2), 5-36.

Kušksis, Jānis. 1996. Fonētikas īpatnības XVI gadsimta rakstos. Baltu filoloǵija, 6, 79-86. 
Kušķis, Jānis. 1998.

Ozols, Arturs. 1965.

Rosinas, Albertas. 2005.

Rudzīte, Marta. 1964.

$\mathrm{SLV}=$

Straubergs, Jānis. 1934.

Straubergs, Jānis. 1936a.

Straubergs, Jānis. 1936b.

Vanags, Pēteris. 1994.

Vanags, Pēteris. 1996.

Vanags, Pēteris. 2000.

Vanags, Pēteris. 2013.

Zanders, Ojārs. 1988.
Dialektālā pamata atspulgs XVI un XVII gadsimta rakstu morfoloǵijā. Baltu filologiija, 8, 68-76.

Veclatviešu rakstu valoda. Rīga: Liesma.

Latviu kalbos daiktavardžio linksniavimo sistema: sinchronija ir diachronija. Vilnius: Mokslo ir enciklopedijų leidybos institutas.

Latviešu dialektologija. Rīga: Latvijas valsts izdevniecība.

Seniespiedumi latviešu valodā, 1525-1855: kopkatalogs = Die älteren Drucke in lettischer Sprache 1525-1855: Gesamtkatalog. Aut. kol. S. Šiško vadībā, zin. red. A. Apīnis. Rīga: Latvijas Nacionālā bibliotēka, 1999.

1615. g. dziesmu hronolog̣ija. Izglītības Ministrijas Mēnešraksts, 12, 534-543.

Latviešu rokas grāmatas 350 gadi. Izglìtïbas Ministrijas Mēnešraksts, 5/6, 471-480.

Latviešu pirmās dziesmu grāmatas. Rīga: Ramave.

16. gadsimta latviešu tekstu avoti. Baltu filoloǵija, 4, 27-42.

Locījumu lietošanas īpatnības vecākajos latviešu rakstos. Baltu filologija, 6, 71-78.

Luterāņu rokasgrāmatas avoti. Vecākā perioda (16.-17. gs. sākuma) latviešu teksti. Stokholma: Memento; Rīga: Mantojums.

Latviešu literārās valodas attīstība. Ilga Jansone, Andrejs Vasks (red.). Latvieši un Latvija 1: Latvieši. Rīga: Latvijas Zinātņu akadēmija, 177-203.

Tipogrāfs Mollīns un viña laiks: Pirmās Rīgā iespiestās grāmatas 1788-1625. Rīga: Zinātne.

Ernesta Kazakènaite

Vilniaus universitetas

Universiteto g. 3, Vilnius, Lietuva

e.kazakenaite@gmail.com

\section{SUMMARY}

\section{Overview of the Collection of the Latvian Pericopes Published in 1587 and 1615: Changes}

\section{Ernesta KAZAKE்NAITE்}

The aim of this paper is to analyse the differences between the first edition of the Euangelia vnd Epiftel pericopes (1587; further EE1) and its second edition (1615; further EE2). The analysis shows that the following changes were made in the second edition of the EE (see also Diagram 1), which include orthographical and morphological changes, as well as derivational, lexical, syntactical and structural changes (few additions but mostly lacunas). The distribution of these types of changes in EE2 is uneven (see Diagram 2) - orthographical changes traced in all pericopes but all other types of changes are sporadic - and appear mostly in the very beginning of the book. It is important to emphasize that in EE2 there are many changes that cannot 
be explained with certainty, and most of them are questionable, as they are most likely to be considered unintentional shifts rather than real corrections.

There are also some extralinguistic data concerning the preparation of EE2 that were found during the analysis. First of all, the inheritance of typographical errors shows that the EE2 text was compiled using a manuscript generated from the EE1 printed text rather than using an unknown earlier manuscript. Second, Diagram 1 clearly shows that there are more changes in the first part of the EE2 pericopes than in the middle or at the end of the book, showing that the beginning of the collection of the pericopes was edited more than the second part. 